\title{
Tidal resuspension of microphytobenthic chlorophyll a in a Nanaura mudflat, Saga, Ariake Sea, Japan: flood-ebb and spring-neap variations
}

\author{
Chul-Hwan Koh ${ }^{1}$, Jong Seong Khim ${ }^{1, *}$, Hiroyuki Araki ${ }^{2}$, Hiroyuki Yamanishi ${ }^{2}$, \\ Hiroyuki Mogi ${ }^{2}$, Kenichi Koga ${ }^{3}$
}

${ }^{1}$ School of Earth and Environmental Sciences (Oceanography), Seoul National University, Seoul 151-742, South Korea

${ }^{2}$ Institute of Lowland Technology, and ${ }^{3}$ Faculty of Science and Engineering, Saga University, Saga 840-8502, Japan

\begin{abstract}
The resuspension of microphytobenthic chlorophyll a (chl a) and suspended particulate matter (SPM) from the upper intertidal flat was studied at Nanaura, Ariake Sea, Japan, and a spatial comparison of chl $a$ and SPM in the northern Ariake Sea is presented here. A $15 \mathrm{~d}$ time series of chl a and SPM records (measured at $15 \mathrm{~cm}$ above the bottom) revealed that resuspension was clearly associated with flood-ebb and spring-neap tidal characteristics, where significant resuspension was found during early flood, particularly in the high-energy period (viz. spring tide). The peaks of resuspended chl $a$ and SPM during 28 tidal periods were observed to consistently occur shortly after the current velocity reached a maximum and when the threshold current velocity was found to be ca. $15 \mathrm{~cm} \mathrm{~s}^{-1}$. Much more highly fluctuating, irregular peaks of chl a and SPM were occasionally observed, these were attributable to high wind speeds, $\geq 3 \mathrm{~m} \mathrm{~s}^{-1}$. Computation of chl $a$ and SPM fluxes showed clear spring-neap variation, and time-integrated fluxes denoted predominant offshore residual transport during the observation period. Benthic chl a measured in the surficial sediment (top $0.5 \mathrm{~cm}$ ) during 13 exposure periods showed a decreasing trend from spring to neap tide, similar to spring-neap variations of chl $a$ in the water column during the semi-lunar tidal period. The daily mean percentage of resuspended chl $a$ in the water column relative to the amount of benthic chl $a$ was estimated to be ca. 10 to $70 \%$ (mean $=33 \%$ ), implying that a certain portion of the microphytobenthos is resuspended during high tide and partly contributes to the total biomass in the water column of the upper intertidal flat.
\end{abstract}

KEY WORDS: Microphytobenthos biomass $\cdot$ Resuspension $\cdot$ Benthic chlorophyll $a \cdot$ Suspended particulate matter $\cdot$ Tidal flats $\cdot$ Ariake Sea

Resale or republication not permitted without written consent of the publisher

\section{INTRODUCTION}

The dynamics of the resuspension of microphytobenthos associated with suspended particles in tidal flat ecosystems are controlled by a variety of factors, such as tidal current, wind stress, and water depth, etc. (Baillie \& Welsh 1980, de Jonge 1995, de Jonge \& van Beusekom 1995, Bassoullet et al. 2000). In macrotidal environments such factors are temporally variable within a tidal cycle, resulting in dynamic resuspension of microphytobenthos and sediment over shorter time scales, from several minutes to hours (Demers et al. 1987, Black 1998). Thus, various factors associated with tidal resuspension should be examined with high temporal resolution (on the order of minutes) throughout the flood-ebb tidal cycle.

However, most studies on tidal resuspension of the microphytobenthos in estuaries and tidal flats have examined the temporal distributions of microphytobenthic chlorophyll a (chl a) on a yearly, seasonal, or monthly basis (de Jonge \& van Beusekom 1992, 1995, de Jonge \& Colijn 1994, McCandliss et al. 2002, Lucas 2003, Lucas et 
al. 2003). Due to the rapid change in environmental variables over tidal cycles, temporal variability in the abundance and composition of microphytobenthos may be great at shorter intervals (i.e. daily or hourly). One study reported that the concentration of microphytobenthic chl $a$ in the shallow zone of a macrotidal estuarine area (St. Lawrence estuary) measured for 5 mo (4 times daily) was highly variable day to day (Demers et al. 1987). However, daily measurements could not fully explain the resuspension dynamics of microphytobenthic chl $a$, including fluctuations from flood to ebb tide. In order to more completely understand the relevant dynamics of microphytobenthic chl a in shallow intertidal flats, it would be necessary to trace their concentrations with high temporal resolution (i.e. hourly or less).

Entrainment of microphytobenthos in the water column, caused by sediment resuspension during flood and ebb tides, is a key process involved in the co-occurrence and redistribution (viz. sedimentation and transport) of microphytobenthic chl a in water (Baillie \& Welsh 1980, de Jonge \& van Beusekom 1992, Blanchard et al. 2001, Lucas 2003). Consequently, resuspended microphytobenthos account for a large part of the total biomass and/or production in the water column. This implies that, in an intertidal flat zone such as the Nanaura mudflat, the biomass and production of microphytobenthos would be more important than that of phytoplankton. For example, in the Dollard, Ems estuary, The Netherlands, suspended microphytobenthos have been reported to contribute up to $92 \%$ of the total primary production (de Jonge 1995). In the Branford Harbor estuary, USA, the resuspension of microphytobenthos from just 10 to $15 \%$ of the top $1 \mathrm{~mm}$ of muddy sediments could fully account for the chl a level in the water column above (Baillie \& Welsh 1980). Given the continuous cycle of resuspension and resedimentation in the tidal flat over the course of each tidal cycle, co-measurement of microphytobenthic chl $a$ in the water and sediment would be needed to understand the dynamics over short time scales.

In the present study, distributions of microphytobenthos in both seawater (10 min intervals during submergence) and sediment $(<1 \mathrm{~h}$ intervals during exposure to air) were examined over a semi-lunar tidal cycle (28 tidal cycles). The objectives of the present study were to: (1) examine the tidal resuspension of microphytobenthos in terms of chl a and suspended particulate matter (SPM), (2) determine the factors affecting the tidal resuspension of chl a and SPM, (3) estimate the proportion of resuspended chl $a$ in water by co-measurement of the chl $a$ in seawater and in bottom sediments on the upper intertidal flat, and (4) report on the overall spatial distribution of microphytobenthic chl $a$ and SPM from the intertidal to subtidal and further offshore in a region of the northern Ariake Sea, Japan.

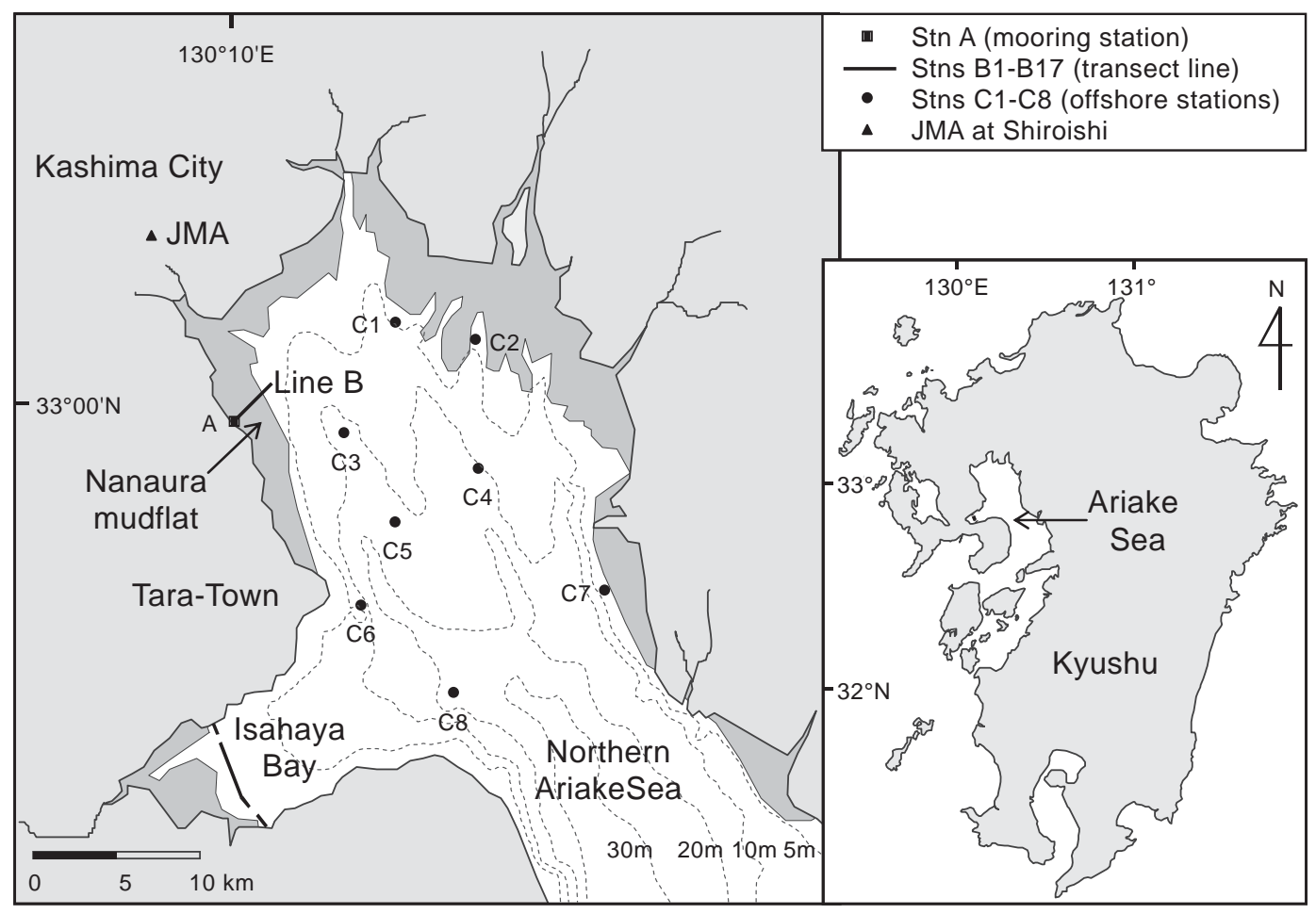

Fig. 1. Study area, Nanaura mudflat, Saga, Ariake Sea, Japan 
Table 1. Details of the field study, summarized for Data Sets I to III (specific purposes are given in parentheses). Chl a: chlorophyll $a_{\text {; }}$ SPM: suspended particulate matter

\begin{tabular}{|c|c|c|c|}
\hline & $\begin{array}{l}\text { Data Set I } \\
\text { (spatial comparisons) }\end{array}$ & $\begin{array}{l}\text { Data Set II } \\
\text { (resuspension data) }\end{array}$ & $\begin{array}{l}\text { Data Set III } \\
\text { (benthic biomass data) }\end{array}$ \\
\hline Samples from: & Seawater $(n=32)$ & Seawater (1301 records) & Sediment $(n=40)$ \\
\hline $\begin{array}{l}\text { Sampling season } \\
\text { (duration) }\end{array}$ & $\begin{array}{l}\text { October } 2002 \\
(2 \mathrm{~d})\end{array}$ & $\begin{array}{l}\text { March-April } 2003 \\
\text { (28 tidal periods) }\end{array}$ & $\begin{array}{l}\text { March } 2003 \\
\text { (13 exposure periods) }\end{array}$ \\
\hline $\begin{array}{l}\text { Sampling location } \\
\text { (site) }\end{array}$ & $\begin{array}{l}\text { Northern Ariake Sea } \\
\text { (Stns A, B1-B17, \& C1-C8) }\end{array}$ & $\begin{array}{l}\text { Upper intertidal, at Nanaura } \\
\text { (Stn } A_{\text {; }} \text { mooring records) }\end{array}$ & $\begin{array}{l}\text { Upper intertidal, } \\
\text { at Nanaura (Stn A) }\end{array}$ \\
\hline $\begin{array}{l}\text { Key parameters } \\
\text { (method) }\end{array}$ & $\begin{array}{l}\text { Chl a (photometric); } \\
\text { SPM (gravimetric) }\end{array}$ & $\begin{array}{l}\text { Chl a (in vivo fluorescence); } \\
\text { SPM (turbidity) }\end{array}$ & $\begin{array}{l}\text { Chl a \& pheopigment } \\
\text { (photometric) }\end{array}$ \\
\hline Data presented in: & Fig. 2 & Tables 2 \& 4, Figs. 3-8 & Tables $3 \& 4$ \\
\hline
\end{tabular}

\section{MATERIALS AND METHODS}

Study area. The Ariake Sea is a semi-enclosed bay located on the western shore of Kyushu, Japan (Fig. 1). Tidal flats are well developed along the shoreline of the northern Ariake Sea, 2 to $5 \mathrm{~km}$ wide in many places, with an estimated total area of about $207 \mathrm{~km}^{2}$. The study area was located in a region dominated by semidiurnal tides, with maximum amplitudes of $\sim 5.5 \mathrm{~m}$ (measured at Daipo port, located $10 \mathrm{~km}$ south of the Nanaura area). The current velocity, measured by a current meter (Compact-EM; Alec Electronics) moored in the upper intertidal flat, ranged from 0.3 to $21 \mathrm{~cm} \mathrm{~s}^{-1}$ (mean $\pm \mathrm{SD}=10 \pm 6 \mathrm{~cm} \mathrm{~s}^{-1}$ ) during flood and from 0.2 to $26 \mathrm{~cm} \mathrm{~s}^{-1}\left(8 \pm 4 \mathrm{~cm} \mathrm{~s}^{-1}\right)$ during ebb tide. The water depth on the upper intertidal flat (at Stn A) was up to 3.2 and $1.3 \mathrm{~m}$ during spring and neap tide, respectively. The water depth varied from 0.4 to $5.5 \mathrm{~m}$ along the transect line of Stns B1 to B17 and between 5 and 24 m for offshore Stns C1 to C8 in the Ariake Sea. The sediment along the shoreline of the Nanaura mudflat was primarily mud with a high water content (>70\%).

Sampling design. The surveys conducted as part of this study can be divided into 3 categories (Data Sets I to III) based on their specific purposes (Table 1). First, to examine overall spatial distribution of microphytobenthic chl $a$ and suspended particles in the northern Ariake Sea, the concentrations of chl $a$ and SPM were measured in seawater collected from the upper intertidal (Stn A), along the transect line (Stns B1 to B17), and offshore (Stns C1 to C8) in October 2002 (Data Set I). From Data Set I, spatial comparisons of chl $a$ and SPM in the upper intertidal and subtidal at Nanaura and offshore in the Ariake Sea are presented (Fig. 2). Second, to determine the short-term dynamics of resuspension in the upper intertidal zone, chl $a$ and SPM in the water column were determined with high temporal resolution, at intervals of 10 min at Stn A from March to April 2003 (Data Set II). These data were col- lected using a mooring sensor coupled with a chlorophyll/turbidity sensor (Compact-CLW; Alec Electronics) and current meter (Compact-EM). The concentrations of chl $a$ and SPM in seawater were automatically measured, together with current velocity and water depth. The data generated covered a full spring to neap tidal cycle (total of 1301 records), encompassing the periods of 28 tidal cycles (see Figs. $3 \& 4$ ). Finally, to determine the benthic biomass of microphytobenthos in the upper intertidal flat, a spatula was used to collect 40 sediment samples from Stn A in 5 spaces of $9.8 \times 1.0$ $\times 0.5 \mathrm{~cm}\left(24.5 \mathrm{~cm}^{-3}\right)$ during 13 of the low-tide exposures in March 2003 (Data Set III; Table 2). The concentrations of chl $a$ and pheopigment and the water content in the surficial sediment were measured (Table 3).

Field measurements. A mooring sensor coupled with a chlorophyll/turbidity sensor (Compact-CLW) and current meter (Compact-EM) was moored (positioned $15 \mathrm{~cm}$ above the bottom) at $\mathrm{Stn} \mathrm{A}$, and the

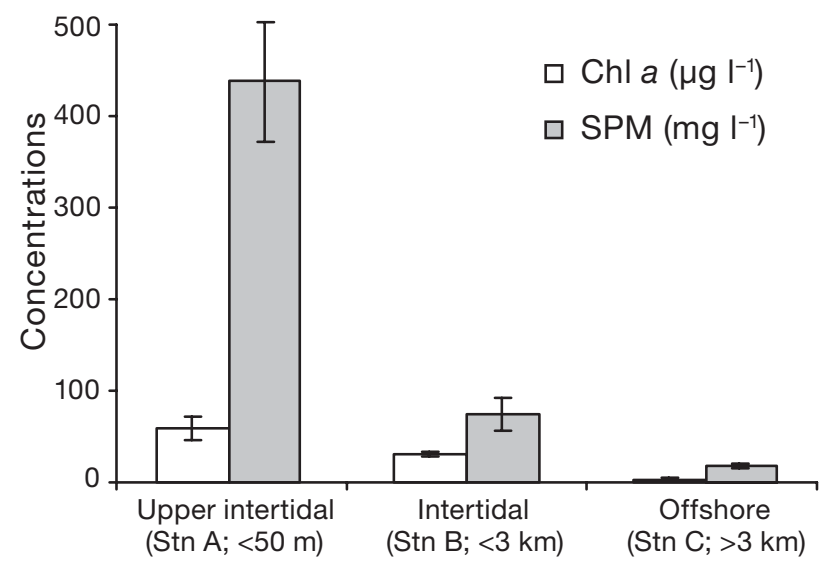

Fig. 2. Spatial comparisons of chl $a$ and suspended particulate matter (SPM) in seawater measured from the upper intertidal (Stn A, $\mathrm{n}=7$ ), the intertidal to subtidal (Stns B1 to $B 17, n=17$ ), and offshore in the Ariake Sea (Stns C1 to C8, $\mathrm{n}=8$ ). Values are given as means $\pm \mathrm{SE}$ 
Table 2. Mean concentrations of chl $a$ and suspended particulate matter (SPM) in seawater from the upper intertidal flat (Stn A), given for 28 flood and ebb tides, respectively. Total chl $a$ and SPM in the water column integrated by depth are given. Conc.: concentration; Integr.: total quantity integrated for the water column. $C_{\mathrm{w}-\mathrm{chl} \text { a-f }}$ is the mean of chl $a$ in the water column during flood tides; $C_{\mathrm{w}-\mathrm{chl} \text { a-e }}$ is the mean of chl $a$ in the water column during ebb tides; $C_{\mathrm{w}-\mathrm{SPM}-\mathrm{f}}$ is the mean of SPM in the water column during flood tides; $C_{\mathrm{w}-\mathrm{SPM} \text {-e }}$ is the mean of SPM in the water column during ebb tides

\begin{tabular}{|c|c|c|c|c|c|c|c|c|c|c|}
\hline \multirow{2}{*}{$\begin{array}{l}\text { Tidal } \\
\text { condition }\end{array}$} & \multirow{2}{*}{$\begin{array}{l}\text { Sampling } \\
\text { date } \\
(2003)\end{array}$} & \multirow{2}{*}{$\begin{array}{l}\text { Tidal cycle } \\
\text { (Nos. 1-28) }\end{array}$} & \multicolumn{4}{|c|}{ Chl $a$} & \multicolumn{2}{|c|}{$C_{C_{\text {w-SPM-f }}} \mathrm{SP}$} & \multicolumn{2}{|c|}{$M$} \\
\hline & & & $\begin{array}{c}C_{\mathrm{w}} \\
\text { Conc. } \\
\left(\mu g \mathrm{l}^{-1}\right)\end{array}$ & $\begin{array}{l}\text { v-chl a-f } \\
\text { Integr. } \\
\left(\mathrm{mg} \mathrm{m}^{-2}\right)\end{array}$ & $\begin{array}{c}C_{\mathrm{w}} \\
\text { Conc. } \\
\left(\mu \mathrm{g} \mathrm{l}^{-1}\right)\end{array}$ & $\begin{array}{l}\text {-chl a-e } \\
\text { Integr. } \\
\left(\mathrm{mg} \mathrm{m}^{-2}\right)\end{array}$ & $\begin{array}{c}C_{\mathrm{w}-} \\
\text { Conc. } \\
\left(\mu \mathrm{g} \mathrm{l}^{-1}\right)\end{array}$ & $\begin{array}{l}\text {-SPM-f } \\
\text { Integr. } \\
\left(\mathrm{mg} \mathrm{m}^{-2}\right)\end{array}$ & $\begin{array}{c}C_{\mathrm{w}} \\
\text { Conc. } \\
\left(\mu \mathrm{g} \mathrm{l}^{-1}\right)\end{array}$ & $\begin{array}{l}\text {-SPM-e } \\
\text { Integr. } \\
\left(\mathrm{mg} \mathrm{m}^{-2}\right)\end{array}$ \\
\hline \multirow[t]{7}{*}{ Spring } & 20 Mar & 1 & 62 & $(111)$ & 50 & (99) & 142 & $(197)$ & 124 & $(227)$ \\
\hline & $20 \mathrm{Mar}$ & 2 & 88 & (143) & 48 & (97) & 289 & (352) & 84 & (157) \\
\hline & $21 \mathrm{Mar}$ & 3 & 48 & $(77)$ & 32 & (74) & 93 & (114) & 59 & (119) \\
\hline & $21 \mathrm{Mar}$ & 4 & 51 & (96) & 45 & (81) & 85 & (119) & 100 & (138) \\
\hline & $22 \mathrm{Mar}$ & 5 & 108 & (165) & 94 & (179) & 495 & (736) & 405 & $(772)$ \\
\hline & $23 \mathrm{Mar}$ & 6 & 92 & (136) & 57 & (95) & 293 & (361) & 84 & (141) \\
\hline & $23 \mathrm{Mar}$ & 7 & 47 & (65) & 36 & (67) & 88 & (91) & 57 & $(94)$ \\
\hline \multirow[t]{14}{*}{ Neap } & $24 \mathrm{Mar}$ & 8 & 48 & (66) & 47 & $(72)$ & 66 & $(74)$ & 49 & (68) \\
\hline & $24 \mathrm{Mar}$ & 9 & 47 & (64) & 45 & (62) & 56 & (65) & 50 & (62) \\
\hline & $25 \mathrm{Mar}$ & 10 & 57 & (54) & 41 & (34) & 50 & (43) & 41 & (29) \\
\hline & 25 Mar & 11 & 25 & (25) & 31 & (30) & 43 & (33) & 48 & (44) \\
\hline & $26 \mathrm{Mar}$ & 12 & 62 & (45) & 36 & (33) & 58 & (37) & 39 & (32) \\
\hline & $26 \mathrm{Mar}$ & 13 & 8.0 & (6.1) & 26 & (18) & 40 & (26) & 58 & (43) \\
\hline & $27 \mathrm{Mar}$ & 14 & 43 & (37) & 46 & (25) & 50 & (44) & 160 & (54) \\
\hline & 27 Mar & 15 & 101 & (33) & 51 & (37) & 440 & (94) & 114 & (93) \\
\hline & $28 \mathrm{Mar}$ & 16 & 35 & (30) & 18 & (22) & 52 & (44) & 44 & (49) \\
\hline & $28 \mathrm{Mar}$ & 17 & 33 & (30) & 27 & (32) & 105 & (78) & 48 & (52) \\
\hline & 29 Mar & 18 & 23 & (27) & 12 & (21) & 42 & (49) & 39 & (57) \\
\hline & $29 \mathrm{Mar}$ & 19 & 30 & (28) & 21 & (31) & 118 & (83) & 42 & (58) \\
\hline & 30 Mar & 20 & 17 & (25) & 13 & (25) & 38 & (54) & 40 & $(75)$ \\
\hline & $30 \mathrm{Mar}$ & 21 & 39 & (50) & 24 & (42) & 158 & (173) & 64 & (108) \\
\hline \multirow[t]{7}{*}{ Spring } & 31 Mar & 22 & 22 & (33) & 13 & $(24)$ & 60 & $(80)$ & 50 & (79) \\
\hline & $31 \mathrm{Mar}$ & 23 & 43 & (55) & 23 & (43) & 184 & (188) & 59 & $(100)$ \\
\hline & $1 \mathrm{Apr}$ & 24 & 56 & (62) & 46 & (60) & 284 & (257) & 203 & (221) \\
\hline & $1 \mathrm{Apr}$ & 25 & 110 & (165) & 70 & (126) & 554 & (789) & 296 & (514) \\
\hline & $2 \mathrm{Apr}$ & 26 & 63 & (104) & 48 & $(87)$ & 214 & (316) & 131 & (192) \\
\hline & $2 \mathrm{Apr}$ & 27 & 98 & (147) & 72 & (131) & 363 & (463) & 142 & (229) \\
\hline & $3 \mathrm{Apr}$ & 28 & 101 & (151) & 85 & (159) & 384 & (525) & 282 & (490) \\
\hline \multicolumn{11}{|l|}{ Mean } \\
\hline \multicolumn{2}{|c|}{ Spring period } & $1-7,22-28$ & 71 & $(108)$ & 51 & (95) & 252 & (328) & 148 & $(248)$ \\
\hline \multicolumn{2}{|c|}{ Neap period } & $8-21$ & 41 & (37) & 31 & (35) & 94 & (64) & 60 & (59) \\
\hline \multicolumn{2}{|c|}{ Entire period } & $1-28$ & 56 & (73) & 41 & (65) & 173 & (196) & 104 & (153) \\
\hline
\end{tabular}

parameters chl a, SPM, current velocity, and water depth were recorded over 28 continuous tidal cycles. The chlorophyll/turbidity sensor and current meter were controlled through a PC serial port, and the main unit in the sensor recorded date and time along with each measurement parameter. The chlorophyll sensor uses fluorescence to determine chl $a$ and an array of 6 light-emitting diodes (LEDs), which provide light in the waveband from 400 to $480 \mathrm{~nm}$ as excitation sources. The light reemitted from fluorescent material that passes through the sampling volume is collected by a receiver diode, with a 640 to $720 \mathrm{~nm}$ optical bandpass filter. Turbidity is determined from the intensity of backscatter of the excitation light; a second receiver diode has an optical bandpass identical to the excitation light, to ensure that the fluorescence activity is not mistaken as turbidity backscatter (Wolk et al. 2001).
The mooring data were corrected based on field and laboratory derived calibrations, and corrected values of chl $a$ and SPM are presented. Based on the inter-calibration between mooring sensor and photometric method, the chl a concentration $\left(\mu \mathrm{g} \mathrm{l}^{-1}\right)$ in seawater measured by the spectrophotometer was not found to be significantly different ( $t$-test, $\mathrm{p}<0.05$ ) from the chl $a$ concentration $\left(\mathrm{mg} \mathrm{l}^{-1}\right)$ recorded by the sensor. The chlorophyll sensor output (in volts) is known to have a significant linear relationship $(\mathrm{p}<0.01)$ with $\mathrm{chl} a$ $\left(\mu \mathrm{g} \mathrm{l}^{-1}\right)$ and with in vivo fluorescence (IVF), estimated from diatom cells; and the slopes of the 2 regression lines are statistically identical ( $t$-test, $\mathrm{p}<0.05$ ) (Wolk et al. 2001). The SPM concentration of seawater measured by the turbidity sensor was corrected based on the regression between sensor turbidity (ppm) and SPM concentration $\left(\mu \mathrm{g} \mathrm{l}^{-1}\right)$ data from field-collected samples $\left(\mathrm{SPM}=1.56 \times\right.$ turbidity $\left.+8.1, \mathrm{r}^{2}=0.99\right)$. 
Table 3. Mean concentrations of chl $a$ and pheopigment (Pheo) in surficial sediment (top $0.5 \mathrm{~cm}$ ) from the upper intertidal flat (Stn A) for 13 exposure periods

\begin{tabular}{|c|c|c|c|c|c|c|c|c|}
\hline $\begin{array}{l}\text { Tidal } \\
\text { condition }\end{array}$ & $\begin{array}{c}\text { Sampling } \\
\text { date (2003) }\end{array}$ & $\begin{array}{c}\text { Exposure } \\
\text { (Nos. 1-13) }\end{array}$ & $\begin{array}{c}\text { Exposure } \\
\text { duration (h) }\end{array}$ & $\begin{array}{l}\text { Sampling } \\
\text { time }(\mathrm{h})\end{array}$ & $\begin{array}{l}\text { Sampling } \\
\text { interval (h) }\end{array}$ & $\begin{array}{c}\text { No. of } \\
\text { sampling }\end{array}$ & $\begin{array}{c}\mathrm{Chl} \mathrm{a} \\
\left(\mu \mathrm{g} \mathrm{m}^{-2}\right)\end{array}$ & $\begin{array}{c}\text { Pheo } \\
\left(\mathrm{mg} \mathrm{m}^{-2}\right)\end{array}$ \\
\hline \multirow[t]{6}{*}{ Spring } & 19 Mar & 1 & 5.5 & $14: 45-15: 45$ & 1.0 & 2 & $151 \pm 5$ & $102 \pm 9$ \\
\hline & 20 Mar & 2 & 5.5 & $14: 10-19: 15$ & 0.7 & 8 & $108 \pm 5$ & $128 \pm 9$ \\
\hline & $21 \mathrm{Mar}$ & 3 & 5.5 & $16: 20-18: 20$ & 1.0 & 3 & $111 \pm 5$ & $134 \pm 7$ \\
\hline & $22 \mathrm{Mar}$ & 4 & 6.0 & $17: 50-19: 50$ & 1.0 & 3 & $87 \pm 4$ & $144 \pm 3$ \\
\hline & $23 \mathrm{Mar}$ & 5 & 4.5 & $05: 50-06: 40$ & 0.5 & 3 & $71 \pm 1$ & $109 \pm 4$ \\
\hline & $23 \mathrm{Mar}$ & 6 & 5.8 & $17: 26-19: 26$ & 1.0 & 3 & $73 \pm 2$ & $115 \pm 6$ \\
\hline \multirow[t]{6}{*}{ Neap } & 24 Mar & 7 & 3.7 & $07: 15-07: 55$ & 0.3 & 3 & $68 \pm 3$ & $127 \pm 17$ \\
\hline & 25 Mar & 8 & 0.0 & $07: 46-08: 46$ & 1.0 & 2 & $66 \pm 3$ & $100 \pm 7$ \\
\hline & 25 Mar & 9 & 5.8 & $19: 11-21: 11$ & 1.0 & 3 & $68 \pm 3$ & $108 \pm 13$ \\
\hline & 26 Mar & 10 & 0.0 & $08: 20$ & - & 1 & $63 \pm 2$ & $73 \pm 2$ \\
\hline & 26 Mar & 11 & 6.3 & $21: 06-23: 06$ & 1.0 & 3 & $76 \pm 2$ & $155 \pm 7$ \\
\hline & 27 Mar & 12 & 0.0 & $11: 20-12: 00$ & 0.3 & 3 & $52 \pm 3$ & $113 \pm 12$ \\
\hline Spring & $31 \mathrm{Mar}$ & 13 & 4.7 & $13: 50-15: 50$ & 1.0 & 3 & $72 \pm 4$ & $95 \pm 5$ \\
\hline \multicolumn{9}{|l|}{ Mean } \\
\hline \multicolumn{2}{|c|}{ Spring period } & $1-6,13$ & 5.4 & & 0.9 & 4 & $96 \pm 29$ & $118 \pm 18$ \\
\hline \multicolumn{2}{|c|}{ Neap period } & $7-12$ & 2.6 & & 0.7 & 3 & $66 \pm 8$ & $113 \pm 27$ \\
\hline \multicolumn{2}{|c|}{ Entire period } & $1-13$ & 4.1 & & 0.8 & 3 & $85 \pm 27$ & $120 \pm 27$ \\
\hline
\end{tabular}

The concentrations of chl $a$ and SPM in the water column were recorded at intervals of $10 \mathrm{~min}$, from mean values of sensor data for every second $(256 \mathrm{~Hz})$. The current velocity was measured every second by an electromagnetic current meter, and a mean value was recorded for each minute. Finally, hourly climate data, such as wind speed, precipitation, and air temperature, were obtained for the corresponding recording period from the Japan Meteorological Agency (JMA) at Shiroishi (Fig. 1).

Laboratory analyses. The concentrations of chl $a$ and SPM in seawater collected from the Nanaura mudflat (Stn A and Stns B1 to B17) and the Ariake Sea (Stns C1 to $\mathrm{C} 8$ ) were measured by photometric and gravimetric analyses. In total, 6 replicates of seawater filters were generated from ca. 3 to 51 water samples using predried and weighed glass fiber filters (GF/F, Whatman) of $47 \mathrm{~mm}$ diameter. The volume filtered ranged from 100 to $1000 \mathrm{ml}$, based on the amount of turbidity observed. For analysis of chl a pigment, 3 of the 6 filters were extracted with acetone $(20 \mathrm{ml})$ for $24 \mathrm{~h}$, in a dark room, at $4^{\circ} \mathrm{C}$. Samples were then centrifuged at $1500 \mathrm{rpm}(56 \times g)$ for $5 \mathrm{~min}$. About $15 \mathrm{ml}$ of supernatant containing pigments was collected and used for determination of absorbance at 665 and $750 \mathrm{~nm}$, before and after acid treatment (Lorenzen 1967). Concentrations of pheopigment in seawater were measured and used for determining a percentage of degraded chl a relative to total chl a. The other 3 filters were used for determination of SPM. SPM concentration was determined gravimetrically after oven drying at $05^{\circ} \mathrm{C}$ for $1 \mathrm{~h}$.

For analyses of sedimentary pigments, samples collected in 5 replicates were pooled together (ca. $30 \mathrm{~g}$ ) and mixed thoroughly. Three sub-samples of ca. $1 \mathrm{~g}$ each were then extracted with acetone, and the chlorophyll pigments were measured as described above. An additional set of 3 sub-samples of ca. $5 \mathrm{~g}$ each was prepared and used for triplicate water content measurements.

Calculations. To understand the dynamics of chl a and SPM in the upper intertidal flat (at Stn A), the depth-integrated chl $a$ and SPM (Fig. 4) were determined by Eq. (1). Assuming a constant vertical chl a distribution, the depth-integrated chl a $\left(\mathrm{mg} \mathrm{m}^{-2}\right)$ and SPM $\left(\mathrm{g} \mathrm{m}^{-2}\right)$ can be estimated as follows:

$$
\int_{0}^{h(t)} C_{\mathrm{w}}(z, t) \mathrm{d} z \approx C_{\mathrm{w}}(t) h(t)
$$

where $t$ is the time, $z$ is the vertical distance from the bottom, $C_{\mathrm{w}}(t)$ is the chl a $\left(\mu \mathrm{g} \mathrm{l}^{-1}\right)$ or SPM $\left(\mathrm{g} \mathrm{l}^{-1}\right)$ concentration in the water column, and $h(t)$ is the time-dependent water depth $(\mathrm{m})$. The fluxes of chl a $\left(\mathrm{g} \mathrm{m}^{-1} \mathrm{~s}^{-1}\right)$ and SPM $\left(\mathrm{mg} \mathrm{m}^{-1} \mathrm{~s}^{-1}\right)$ were calculated by multiplying the depth-integrated chl $a$ and SPM by the current velocities $\left(\mathrm{cm} \mathrm{s}^{-1}\right)$ (Fig. 5). Further, time-integrated chl a and SPM $\left(\mathrm{kg} \mathrm{m}^{-1}\right)$ values were calculated, representing the residual fluxes of chl $a$ and SPM during the observation period (Bassoullet et al. 2000).

Next, to estimate the resuspended portion of total chl $a$ in the water column during flood-ebb submergence, the resuspended chl a $\left(C_{\mathrm{w} \text {-resus }}\right)$ for every measurement during flood $\left(C_{\mathrm{w}-\text { resus-f }}\right)$ and ebb $\left(C_{\mathrm{w} \text {-resus-e }}\right)$ tides was derived from Eq. (2), in units of mass per square meter:

$$
C_{\mathrm{w}-\text { resus }}(t) \times h(t)=\left[C_{\mathrm{w}}(t)-C_{\mathrm{w} \text {-base }}(t)\right] h(t)
$$



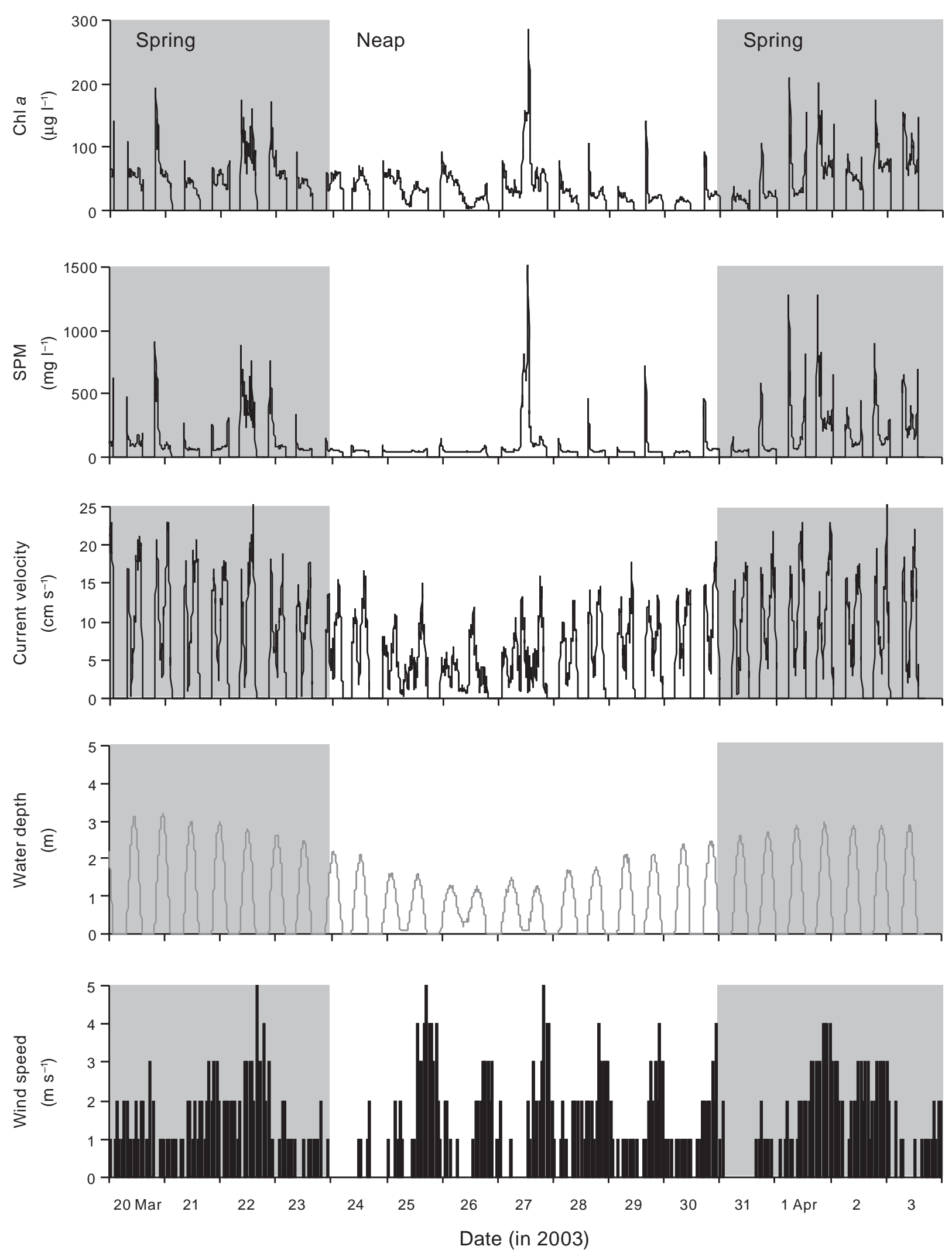

Fig. 3. Temporal changes in chl a and suspended particulate matter (SPM) concentrations in seawater measured at Stn A from the upper intertidal flat over 28 tidal cycles (mooring records). Corresponding current velocity, water depth, and wind speed are presented as well. Shaded sections indicate data for spring-tide, while open sections represent data for neap-tide periods 
Chl $a_{\text {resus }}[-]$ SPM [-] Current velocity [+] Water depth [- ] Spring [ No ] Neap [으]
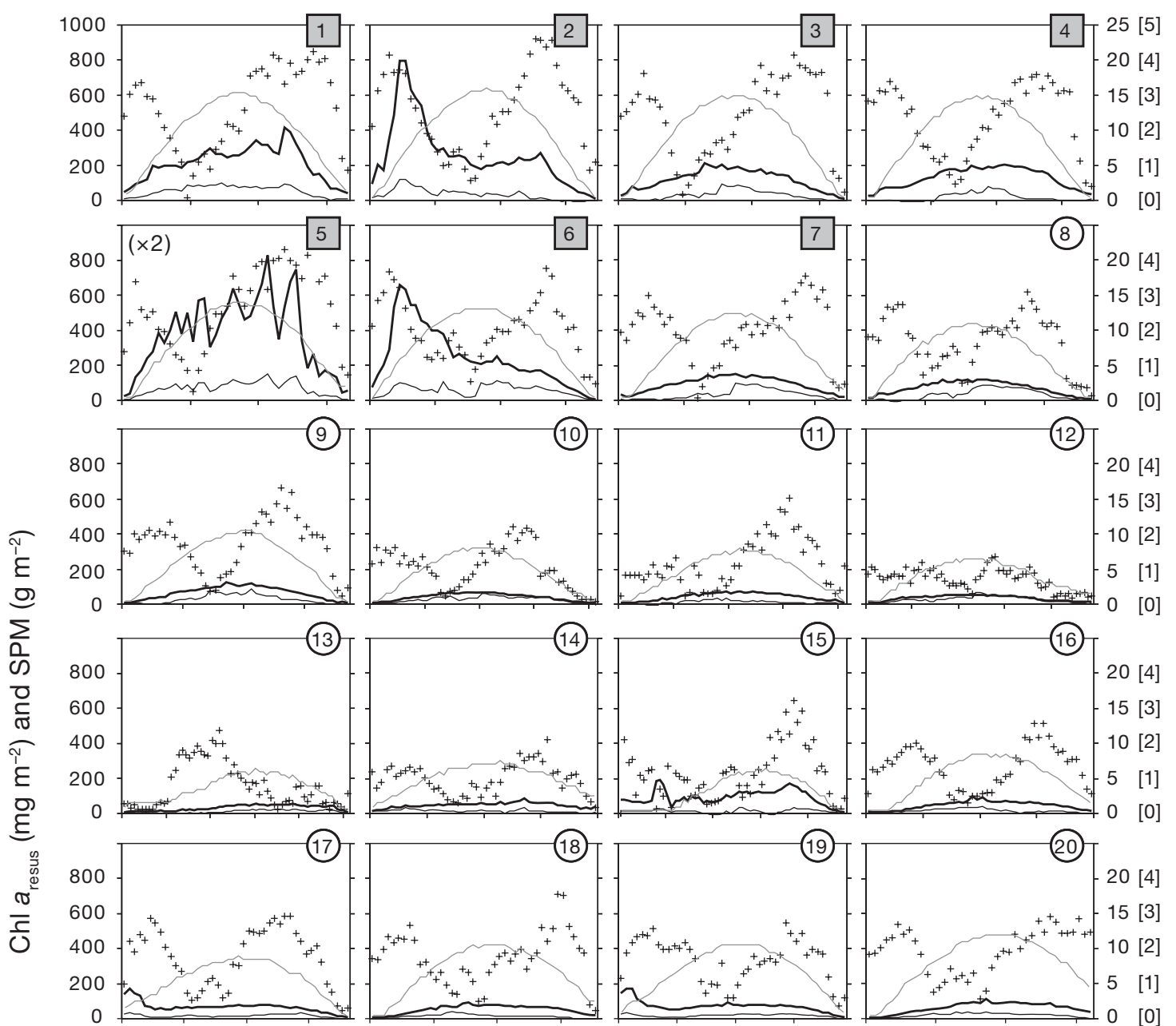

$\begin{array}{rr}20 & {[4]} \\ 15 & {[3]} \\ -10 & {[2]} \\ 5 & {[1]} \\ 0 & {[0]}\end{array}$
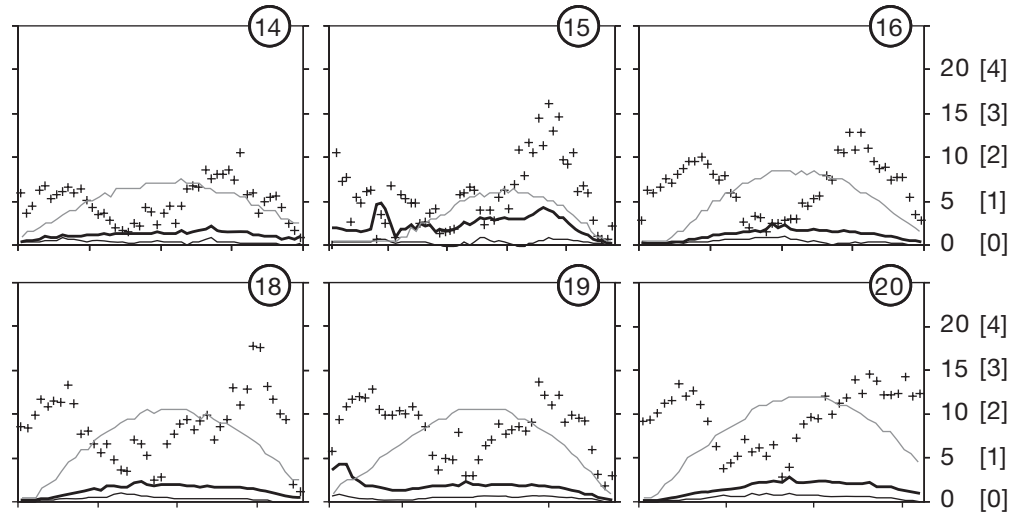

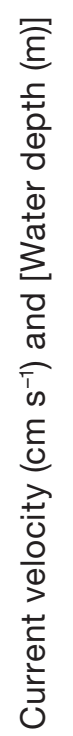
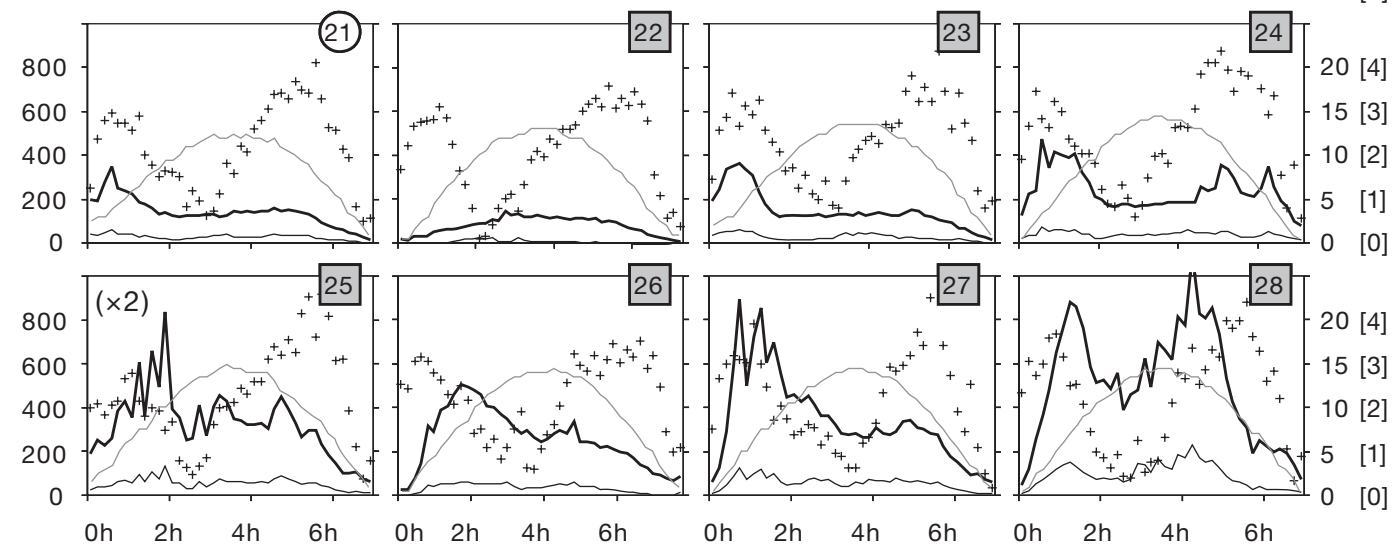

Elapsed Hour

( $0 \mathrm{~h}$ : beginning of flood, time scale in $2 \mathrm{~h}$ interval)

Fig. 4. Temporal changes in depth-integrated resuspended chl a (chl $a_{\text {resus}}$ ) and suspended particulate matter (SPM) in seawater measured at Stn A from the upper intertidal flat over 28 tidal cycles. Corresponding current velocity and water depth are presented as well. Note that chl $a$ and SPM data from tidal cycles No. 5 and No. 25 have $y$-axis values that are double the scale $(\times 2)$ relative to the other panels; number at the upper right of each panel: number of tidal cycle 
where $t$ is the time, $C_{\mathrm{w}}(t)$ is the chl a $\left(\mu \mathrm{g} \mathrm{l^{-1 }}\right)$ concentration in the water column, and $h(t)$ is the timedependent water depth $(\mathrm{m})$. The baseline concentration of chl $a$ in the water column $\left(C_{\mathrm{w} \text {-base }}\right)$ was estimated from the relationship between chl $a$ and SPM ( $b$ in [chl $a=a \times \mathrm{SPM}+b]$ ) for every ebb and flood tide.
Finally, the mean of resuspended chl $a$ in the water column during flood submergence:

$$
C_{\text {w-resus-fi }} \int_{0}^{T_{\text {flood }}} C_{\text {w-resus }}(t) h(t) \mathrm{d} t / T_{\text {flood }}
$$

and ebb submergence:

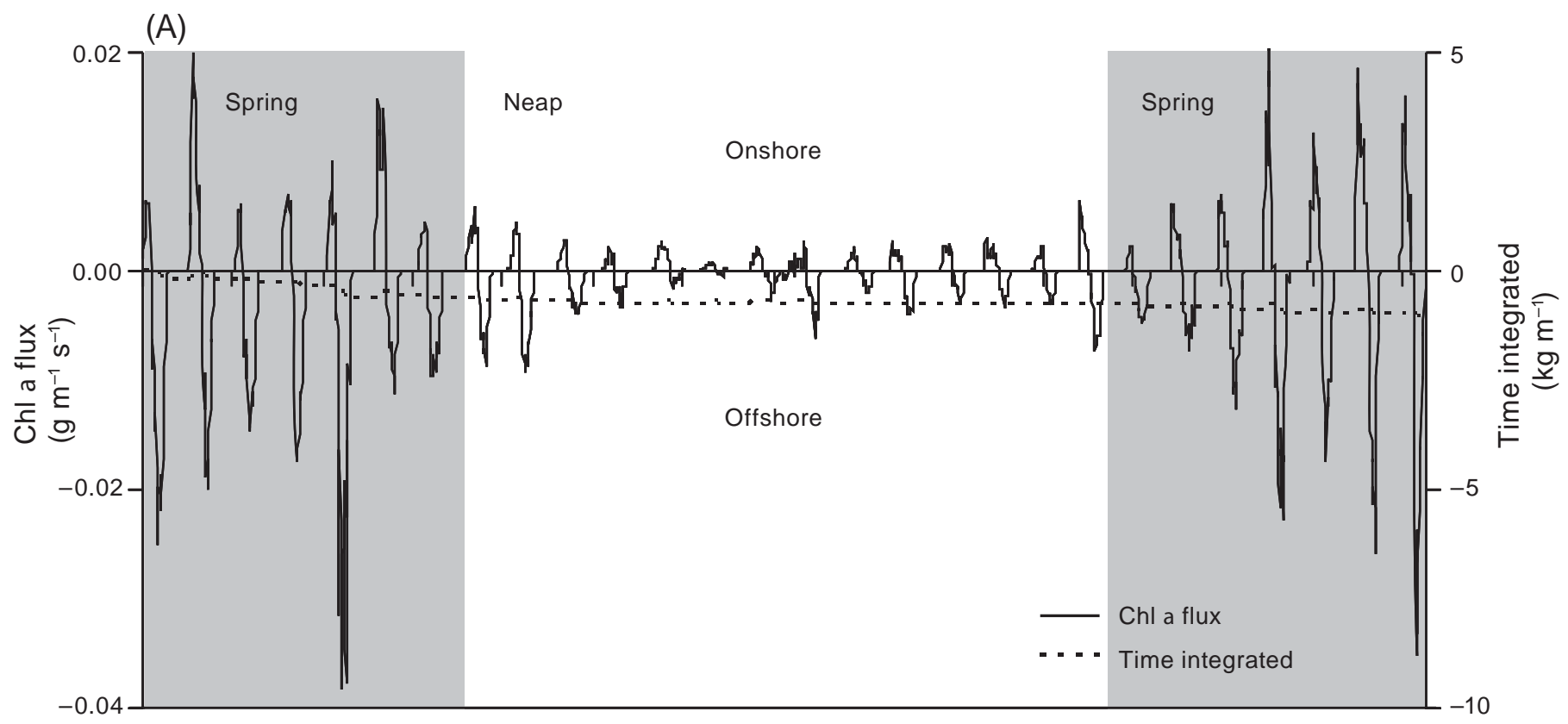

(B)

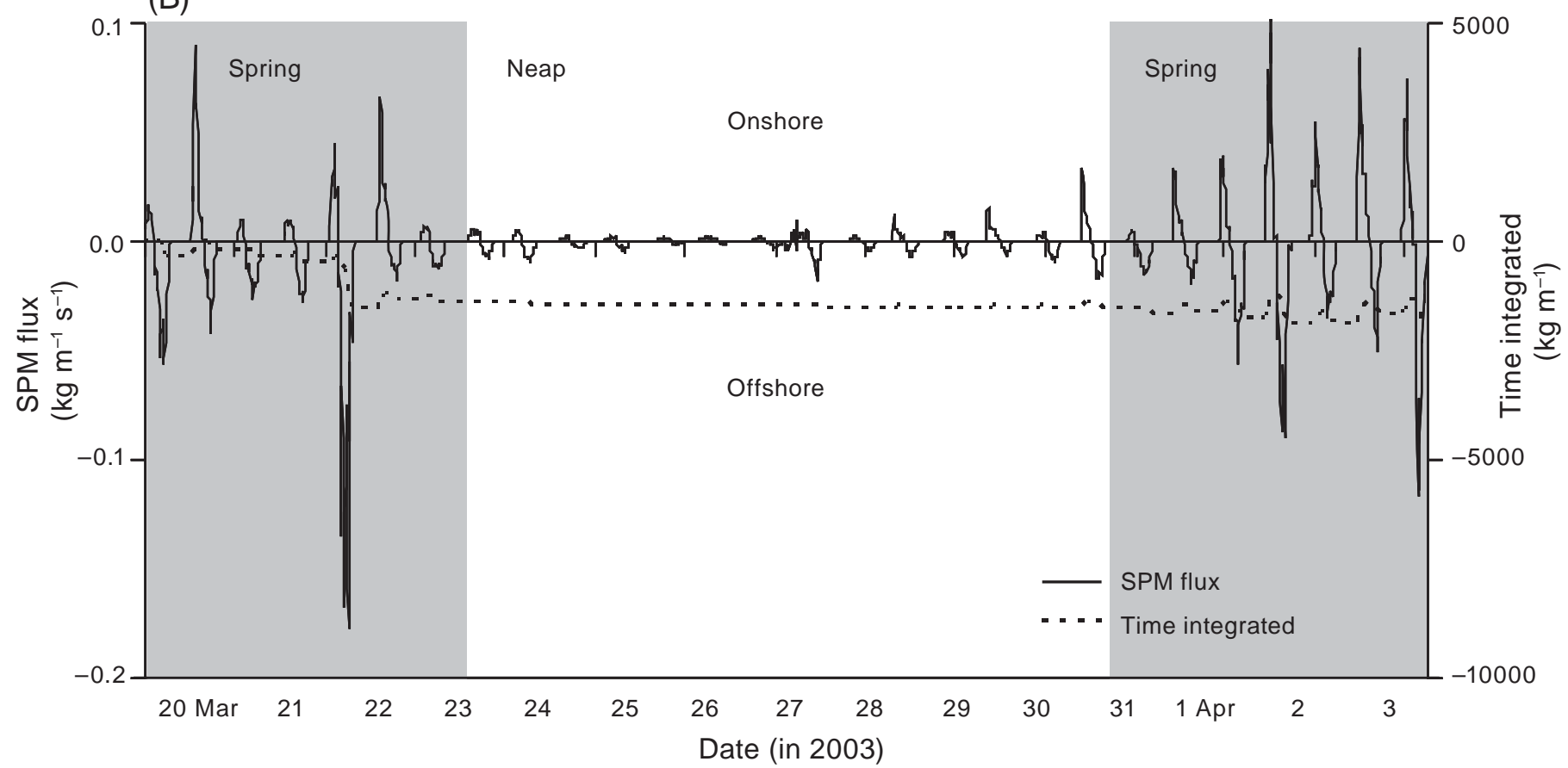

Fig. 5. Fluxes of (A) chl $a$ and (B) suspended particulate matter (SPM) in seawater measured at Stn A from the upper intertidal flat over 28 tidal cycles. Dots indicate time-integrated chl $a$ and SPM during the observation periods. Positive/negative values represent the onshore/offshore fluxes, respectively. Shaded sections indicate data for spring-tide, while open sections represent data for neap-tide periods 
Table 4. Chl $a$ in sediment measured shortly before flood and the mean of resuspended chl $a$ in seawater during succeeding flood and ebb tides from the upper intertidal flat (Stn A), followed by the ratios of chl $a$ in seawater to that in surficial sediment

\begin{tabular}{|c|c|c|c|c|c|c|}
\hline & & \multirow{2}{*}{$\begin{array}{c}\text { Sediment } \\
C_{\text {sed }} \\
\left(\mathrm{mg} \mathrm{m}^{-2}\right)\end{array}$} & \multicolumn{2}{|c|}{ Seawater } & \multicolumn{2}{|c|}{ Seawater / Sediment } \\
\hline & & & $\begin{array}{l}C_{\text {w-resus-f }} \\
\left(\mathrm{mg} \mathrm{m}^{-2}\right)\end{array}$ & $\begin{array}{l}C_{\text {w-resus-e }} \\
\left(\mathrm{mg} \mathrm{m}^{-2}\right)\end{array}$ & $\begin{array}{c}C_{\text {w-resus-f }} / C_{\text {sed }} \\
\text { (ratio) }\end{array}$ & $\begin{array}{c}C_{\text {w-resus-e }} / C_{\text {sed }} \\
\text { (ratio) }\end{array}$ \\
\hline \multirow[t]{5}{*}{ Spring } & 20 Mar & 151 & 58 & 47 & 0.37 & 0.30 \\
\hline & 21 Mar & 123 & 53 & 12 & 0.35 & 0.08 \\
\hline & 22 Mar & 89 & 14 & 19 & 0.12 & 0.15 \\
\hline & 23 Mar & 76 & 55 & 64 & 0.61 & 0.71 \\
\hline & 23 Mar & 63 & 16 & 50 & 0.22 & 0.66 \\
\hline \multirow[t]{6}{*}{ Neap } & 24 Mar & 62 & 15 & 47 & 0.23 & 0.74 \\
\hline & 25 Mar & 63 & 28 & 27 & 0.46 & 0.43 \\
\hline & 25 Mar & 69 & 9 & 8 & 0.14 & 0.13 \\
\hline & 26 Mar & 63 & 22 & 30 & 0.31 & 0.44 \\
\hline & 26 Mar & 73 & 16 & 10 & 0.22 & 0.13 \\
\hline & 27 Mar & 47 & 11 & 13 & 0.24 & 0.27 \\
\hline Spring & 31 Mar & 84 & 31 & 20 & 0.37 & 0.24 \\
\hline \multicolumn{7}{|l|}{ Mean $\pm \mathrm{SD}$} \\
\hline Spring period & & $98 \pm 33$ & $38 \pm 20$ & $35 \pm 21$ & $0.34 \pm 0.17$ & $0.36 \pm 0.27$ \\
\hline Neap period & & $63 \pm 9$ & $17 \pm 7$ & $22 \pm 15$ & $0.27 \pm 0.11$ & $0.36 \pm 0.23$ \\
\hline Entire period & & $80 \pm 29$ & $27 \pm 18$ & $29 \pm 19$ & $0.30 \pm 0.14$ & $0.36 \pm 0.24$ \\
\hline
\end{tabular}

$$
C_{\text {w-resus-ei }} \int_{0}^{T_{\text {ebb }}} C_{\text {w-resus }}(t) h(t) \mathrm{d} t / T_{\text {ebb }}
$$

was calculated, then compared with sediment chl a $\left(C_{\text {sedi }}\right.$ measured shortly before flood tide began), both in units of mass per square meter, in order to estimate the proportion of resuspended chl a relative to chl a present in surficial sediment $(0$ to $0.5 \mathrm{~cm})$. Twelve daily mean ratios $\left(C_{\mathrm{w}-\text { resus }} / C_{\mathrm{sed}}\right)$ of resuspended chl $a$ in seawater to benthic chl $a$ in sediment at Stn A were obtained (Table 4).

\section{RESULTS}

\section{Tidal condition}

The current velocity recorded in the upper intertidal flat for $15 \mathrm{~d}$ (28 tidal cycles; Nos. 1 to 28) showed regular fluctuation during flood-ebb and spring-neap tides, ranging from 0.2 to $26 \mathrm{~cm} \mathrm{~s}^{-1}$. Maximal current velocity was generally observed twice per tidal cycle, in early flood tide and in the middle of ebb tide, while the minimum current velocity at the high slack water period was recorded to range from 0.3 to $3.9 \mathrm{~cm} \mathrm{~s}^{-1}$ (Fig. 3). Current velocity rapidly increased up to $21 \mathrm{~cm}$ $\mathrm{s}^{-1}$ during the first $30 \mathrm{~min}$ of flood tide. The corresponding water depth was generally $<0.5 \mathrm{~m}$. Overall, current velocities were found to be more variable during flood $\left(10 \pm 6 \mathrm{~cm} \mathrm{~s}^{-1}\right)$ than ebb $\left(8 \pm 4 \mathrm{~cm} \mathrm{~s}^{-1}\right)$ tide, indicating more dynamic environmental conditions during the flood period. The current velocities showed great variability during the spring (tidal cycle Nos. 1 to 7 )-neap
(Nos. 8 to 21)-spring (Nos. 22 to 28) tidal period, when the mean current velocity was approximately twice as great at spring $\left(12 \pm 5 \mathrm{~cm} \mathrm{~s}^{-1}\right)$ as at neap $\left(7 \pm 4 \mathrm{~cm} \mathrm{~s}^{-1}\right)$ tide. In particular, the current velocities during the first $20 \mathrm{~min}$ of the early flood tide were greatly reduced (from 14 to $4.5 \mathrm{~cm} \mathrm{~s}^{-1}$ ) from spring to neap tide, suggesting lower tidal energy followed by reduced tidal current during neap tide.

\section{Spatial comparison of $\mathrm{chl} a$ and SPM}

Concentrations of chl $a$ and SPM in seawater measured at Stns A, B, and C were high at upper intertidal, lower at subtidal, and lowest at offshore stations (Data Set I; Fig. 2). Concentrations of chl $a$ and SPM in seawater measured during flood tide varied considerably with time, with mean concentrations $(\mathrm{n}=7)$ of $60 \mu \mathrm{g} \mathrm{l}^{-1}$ and $438 \mathrm{mg} \mathrm{l}^{-1}$, respectively. The concentrations of chl a $\left(57 \mu \mathrm{g} \mathrm{l}^{-1}\right)$ and SPM (316 $\mathrm{mg} \mathrm{l}^{-1}$ ) from Stn B1 were the greatest among the cross-section stations (from Stns B1 to B17), and were comparable to those measured at Stn A. Concentrations of chl a and SPM decreased approaching the subtidal zone, with concentrations at Stn B17 being 5- to 10-fold lower than those at Stn B1. The chl $a$ and SPM concentrations at stations $>2 \mathrm{~km}$ from the shore (Stns B16 and B17) were relatively consistent and were similar to or slightly greater than concentrations detected at offshore stations (Stns C1 to C8). Mean concentrations of chl a $\left(3.0 \mu \mathrm{g} \mathrm{l}^{-1}\right)$ and SPM (18 $\mathrm{mg}^{-1}$ ) at Stn $\mathrm{C}$ were significantly lower than those detected in the upper intertidal flat, in general (Fig. 2). 
From the upper intertidal to subtidal zone, the ratio of chl a/SPM gradually increased, and reached maximum of ca. $1.1 \times 10^{-3}$ (viz. $1100 \mu \mathrm{g} \mathrm{g}^{-1}$ ) at Stns B13 to B14 ( 1.5 km off the coastline), but rapidly decreased down to $0.5 \times 10^{-3}$ (viz. $500 \mu \mathrm{g} \mathrm{g}^{-1}$ ) at the last station (B17). This could be due to the relatively rapid decreases in chl $a$ at Stns B16 and B17, with only small variations in the cross-sectional distribution of SPM (26 to $29 \mathrm{mg} \mathrm{l}^{-1}$ ) at the outer stations (B13 to B17). The ratios of chl a/SPM offshore in the Ariake Sea decreased further down to tens of micrograms per gram at some stations (mean $=177 \mu \mathrm{g} \mathrm{g}^{-1}$ ). Decreases in $\mathrm{chl}$ a/SPM in the offshore region resulted from lower chl a concentrations, ranging from 0.89 to $10 \mu \mathrm{g} \mathrm{l}^{-1}$, with less input of resuspended chl $a$ into the water column due to the weak tidal current in deep water (5 to $24 \mathrm{~m}$ ). This phenomenon was confirmed by the lack of correlation $\left(\mathrm{r}^{2}=0.01, \mathrm{p}<0.05\right)$ between chl $a$ and SPM in the water column at offshore stations.

\section{Flood-ebb distribution of chl $a$ and SPM}

The chl $a$ and SPM concentrations in seawater at Stn A from the upper intertidal flat were measured with high temporal resolution by use of mooring sensors (Data Set II). Flood tide concentrations of chl $a$ and SPM were usually greater than concentrations at ebb tide $(>80 \%$ of the time during the observation period of 28 tidal cycles). Mean concentrations of chl a were found to be 56 and $41 \mu \mathrm{g} \mathrm{l^{-1 }}$ during flood and ebb tides, respectively, and corresponding mean SPM values were 173 and $104 \mathrm{mg} \mathrm{l}^{-1}$ during flood and ebb tides, respectively (Table 2). The maximum concentrations of chl $a$ and/or SPM were mostly found during the first 20 min of flood tide (except for tidal cycle No. 20), although the current velocity did not reach maximum until ca. 30 min after recording began (Fig. 3). Considering the great variations ( 0.1 to $3.2 \mathrm{~m}$ ) in water depth caused by flood-ebb tides, depth-integrated values of chl a $\left(\mathrm{mg} \mathrm{m}^{-2}\right)$ and SPM $\left(\mathrm{g} \mathrm{m}^{-2}\right)$ were used to clearly reveal the resuspended amounts in the water column over time (values in units of mass per square meter). A sudden peak in resuspended chl a or SPM was clearly observed shortly after the maximum current velocity was detected (Fig. 4). This phenomenon usually occurred during spring tide (e.g. tidal cycle Nos. 2, 5, 6, 23 to 28), due to the relatively fast tidal current, with a maximum current velocity of $>15 \mathrm{~cm} \mathrm{~m}^{-1}$. Although tidal current speed increased rapidly during the middle of ebb tide, peaks in resuspended chl a or SPM were rarely found during this time and were often comparable or close to concentrations observed during the high slack water period. However, elevated resuspended chl $a$ and SPM values have been found occa- sionally during periods of slack water and ebb tide when wind speeds were $>2$ to $5 \mathrm{~m} \mathrm{~s}^{-1}$. On average, concentrations of chl $a$ and SPM resuspended in the water column increased 92 and $37 \%$, respectively, during high-wind periods compared to those during lowwind periods. Thus, both current velocity and wind speed are related to resuspension of chl $a$ and SPM in the water column in the upper intertidal zone at Nanaura.

\section{Spring-neap distribution of chl $a$ and SPM}

On average, the chl a concentration in seawater during spring tide (mean $\pm \mathrm{SD}: 61 \pm 27 \mu \mathrm{g} \mathrm{l}^{-1}$ ) was approximately 1.7 times greater than that during neap tide $\left(36 \pm 19 \mu \mathrm{g} \mathrm{l}^{-1}\right)$. Similarly, the spring-neap variation in SPM concentration was clearly observed by a ca. 2.6-fold difference, on average, whereby the maximum spring SPM (450 mg $\mathrm{l}^{-1}$; tidal cycle No. 5) was approximately 10 -fold greater than the minimum neap SPM recorded (45 $\mathrm{mg} \mathrm{l}^{-1}$; tidal cycle No. 11). Spring-neap differences in chl $a$ and SPM concentrations were observed throughout the tidal periods of flooding (2.7- and 5.8-fold), slack water (2.4- and 3.9-fold), and ebbing (2.4- and 4.2-fold). These trends may be broadly explained by the differences in tidal current velocity during spring and neap tides, since the current velocity decreased approximately by a factor of $>2.0$ from spring to neap tide. Similarly, fluxes of chl a and SPM increased during spring tide, whereas relatively low net fluxes were observed during the neap period, indicating lower fluxes in both onshore and offshore directions (Fig. 5). Within the tide, the peak of chl a flux in the ebbing direction was greater than that in the flooding direction, especially during the springtide period. Clear spring-neap variability was observed within the tide for SPM flux as well.

Benthic chl a measured in surficial sediment $(0$ to $0.5 \mathrm{~cm}$ ) during 13 exposure periods at Stn A showed spring-neap variations similar to those observed in the water column during the semi-lunar tidal period, i.e. sediment chl a tended to decrease gradually from 151 (Exposure No. 1; spring) to $52 \mathrm{mg} \mathrm{m}^{-2}$ (Exposure No. 12; neap) (Table 3). Greater benthic biomass of microphytobenthos in the sediment during the springtide period could be related to the longer duration of daytime exposure during the spring- $(5.4 \mathrm{~h})$ compared to that during the neap-tide period $(2.6 \mathrm{~h})$, whereas corresponding pheopigment concentrations in the sediment did not vary greatly during spring-neap tidal periods. Thus, the effect of benthic grazing does not seem to be directly related to spring-neap tidal conditions. The ratio of resuspended chl a present in the water column relative to sediment chl a showed 
great daily variation from 0.12 to 0.71 during 12 exposure-submersion periods (Table 4 ). As much as $71 \%$ of the resuspended chl $a$ in the water column came from sediment chl $a$, which indicated a great contribution of benthic-derived chl $a$ in the water column during flood-ebb submergence. Although a detailed taxonomic study was not carried out in the present study,
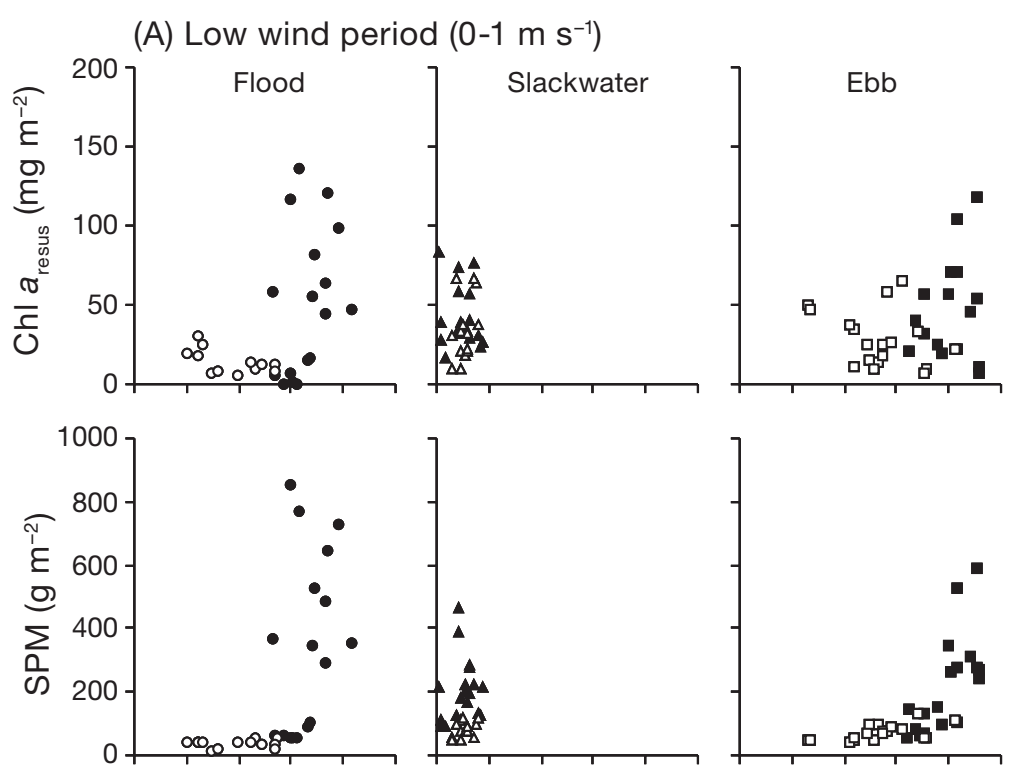

(B) High wind period (2-5 $\left.\mathrm{m} \mathrm{s}^{-1}\right)$
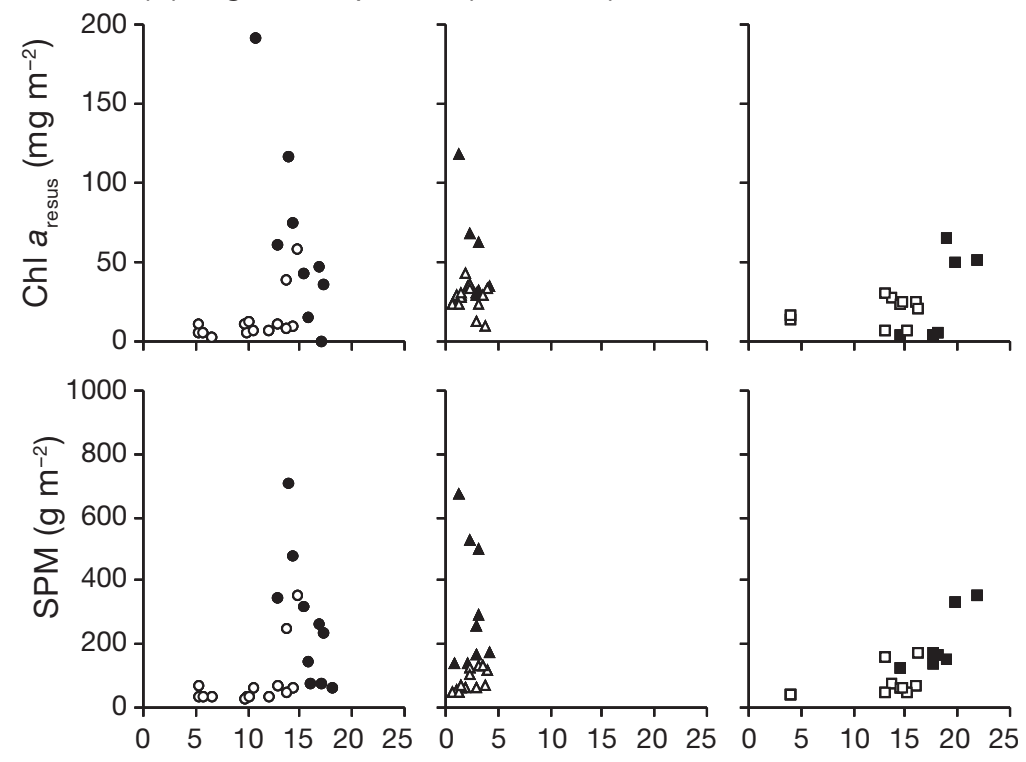

Current velocity $\left(\mathrm{cm} \mathrm{s}^{-1}\right)$

Fig. 6. Plots of resuspended $\mathrm{chl}$ a ( $\left.\mathrm{chl} a_{\text {resus }}\right)$ and suspended particulate matter (SPM) in seawater against the current velocity measured at Stn A from the upper intertidal flat, during periods of flood, slack water, and ebb tides. Data presented for periods of (A) low wind speed (0 to $1 \mathrm{~m} \mathrm{~s}^{-1}$ ) and (B) high wind speed $\left(2\right.$ to $\left.5 \mathrm{~m} \mathrm{~s}^{-1}\right)$. Closed symbol = spring-tide, open symbol $\mathrm{O}=$ neap-tide microscopic observation of sediment microalgae indicated that diatoms (Gyrosigma, Navicula, Nitzschia, Tryblionella) constituted $>90 \%$ of the total microalgae present. Both benthic and planktonic species were present in the sediment, but the small proportion of pelagic and large centric diatoms (such as Coscinodiscus spp.) indicated that chl a measured in the sediment primarily represented the microphytobenthic chl a.

\section{DISCUSSION}

Tide- and wind-induced resuspension

Several studies have reported that both tidal currents and wind-induced waves are prominent factors associated with the resuspension and transport of sediment and associated biological particles in estuary and tidal flat environments (Demers et al. 1987, de Jonge 1995, Black 1998, de Jonge \& van Beusekom 1995). Tide- and windinduced resuspension of microphytobenthos and mud appear to be location specific and related to sediment properties and species composition as well (de Jonge \& van Beusekom 1995). Thus, to find factors associated with the tidal resuspension of chl $a$ and/or SPM in the upper intertidal flat at Nanaura, data recorded from 28 tidal cycles were examined. First, data points were selected from those at the maximum (top of 2 each at flood and ebb periods) and minimum (bottom of 2 at high slack water period) current velocities recorded, respectively. Depth-integrated amounts of resuspended chl a (denoted chl $a_{\text {resus }}$ ) and SPM were plotted against corresponding current velocity (Fig. 6). Elevated chl $a$ and SPM were clearly observed at current velocities above $\sim 15$ to $20 \mathrm{~cm} \mathrm{~s}^{-1}$ during flood tide, indicating simultaneous resuspension of chl $a$ and SPM during the early flood period. The resuspended chl $a$ and SPM decreased as a result of settlement in response to decreased current velocity during the high slack water period. However, during the ebb period, chl $a$ and SPM seemed to be still suspended in the water column at current velocities greater than ca. $20 \mathrm{~cm} \mathrm{~s}^{-1}$, but settled out as current velocity declined.

To clearly discriminate the wind effect from the tidal current effect, we segregated 
(A) Spring period
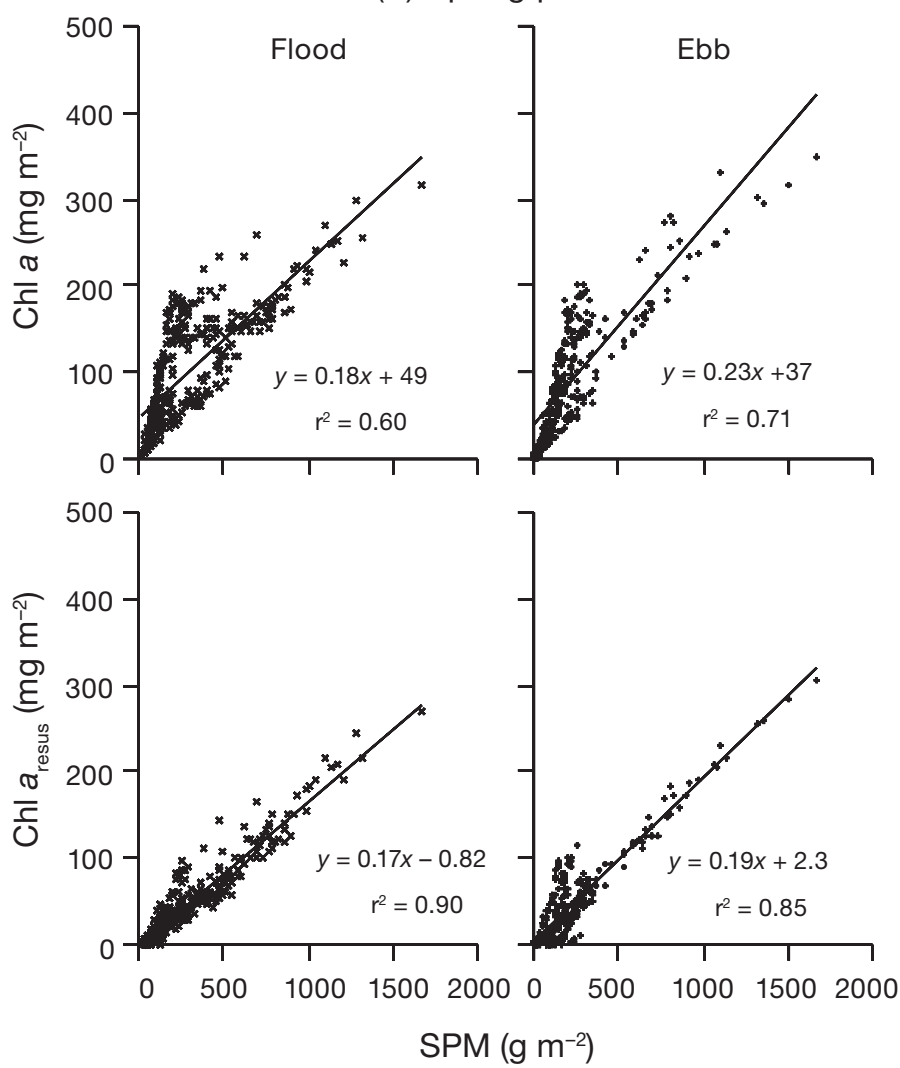

(B) Neap period
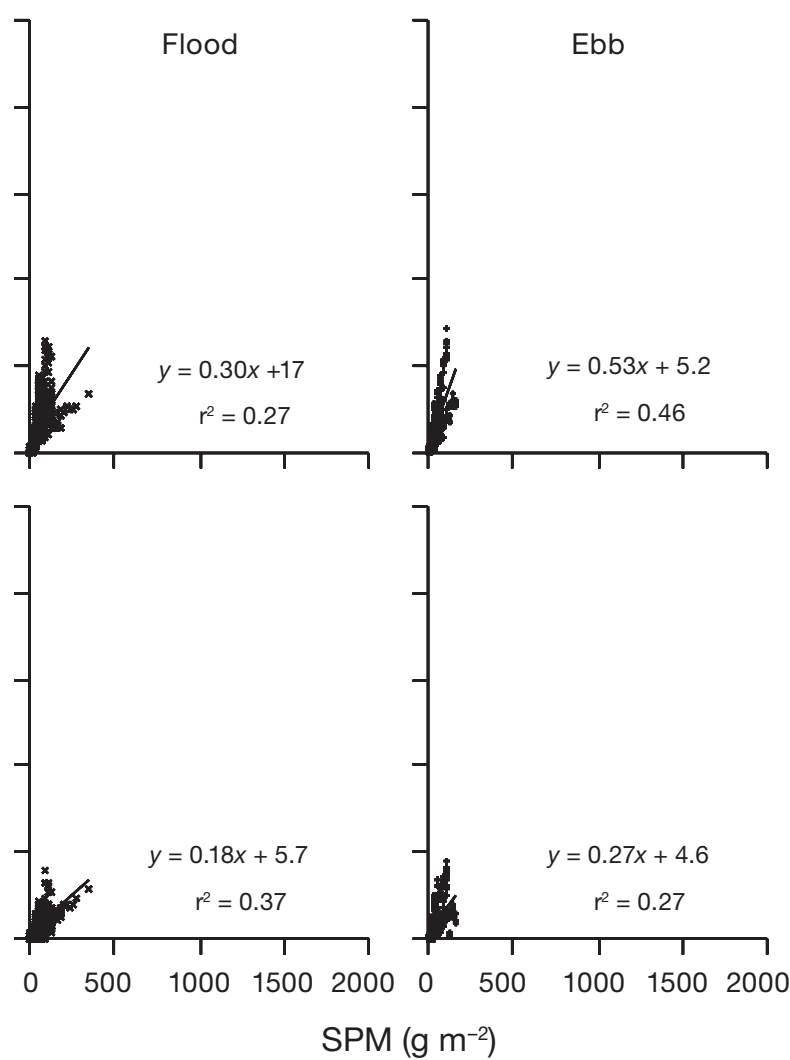

Fig. 7. Relationship between $\mathrm{chl}$ a or $\operatorname{chl} a_{\text {resus }}$ and suspended particulate matter (SPM) measured at Sth A from the upper intertidal flat, during flood and ebb. Data presented for periods of (A) spring and (B) neap periods

data points based on the wind speed recorded (viz. into low- [Fig. 6A] and high-wind periods [Fig. 6B]). This was done because the effect of current velocity on tidal resuspension can be over- or underestimated due to the combined effects of tidal current and wind stress. Although resuspension of flood or ebb SPM was ca. 1.7-fold greater during the high-wind period (2 to 5 $\mathrm{m} \mathrm{s}^{-1}$ ) than the low-wind period (0 to $1 \mathrm{~m} \mathrm{~s}^{-1}$ ), the erosion threshold of current velocity for suspended particles between high- and low-wind periods did not vary. Thus, wind speed may not be directly related to the SPM erosion process; tidal current may be the primary factor controlling SPM resuspension in the upper intertidal flat at Nanaura. However, a wind effect on SPM resuspension was often found during the high slack water period, when wind speeds were $\geq 3 \mathrm{~m} \mathrm{~s}^{-1}$ (Fig. 6B). Moreover, ca. $75 \%$ of the highly elevated SPM (>200 $\mathrm{mg} \mathrm{l}^{-1}$ ) during flood tide was attributable to high wind speed ( 2 to $5 \mathrm{~m} \mathrm{~s}^{-1}$ ), in particular windinduced resuspension of SPM was stronger when water depth was $<0.5 \mathrm{~m}$ and vice versa. The effective wind speed $\left(\geq 3 \mathrm{~m} \mathrm{~s}^{-1}\right)$ for SPM resuspension found in this study was similar to that $\left(4 \mathrm{~m} \mathrm{~s}^{-1}\right)$ reported by Demers et al. (1987). Furthermore, consideration of local wind effects and other physical disturbances during the sampling period would improve characterization of the effect of wind on SPM resuspension.

Overall, the resuspension of chl a during the early flood and/or ebb tide was apparently related to both tidal current and wind waves. Considering the lower current velocity of $<15 \mathrm{~cm} \mathrm{~s}^{-1}$ during neap tide, the resuspension of chl a and/or SPM usually took place during the spring-tide period, due to high tidal energy. Several studies have reported the erosion thresholds of microalgae or suspended particles based on flume and/or field experiments; in these reports resuspension occurred at current velocities between 10 and $20 \mathrm{~cm}$ $\mathrm{s}^{-1}$ (de Jonge \& van den Bergs 1987, Lucas et al. 2000, Widdows et al. 2000, Jago et al. 2002). However, it should be noted that threshold current velocities would (increase or decrease) under natural conditions, due to differences in sediment type and composition/abundance of stabilizers (benthic algal films) or destabilizes (bioturbating benthic fauna) (Lucas et al. 2000, Widdows et al. 2000). Further, the exposure duration would influence the stability of the surface sediment, resulting in a shift of threshold current velocity. For example, microphytobenthos on surficial 
sediment can be readily resuspended when the extracellular polymeric substances produced are unable to consolidate due to a short exposure duration (Lucas et al. 2000). Considering the shorter exposure duration during neap (2.6 h) in comparison to spring (5.4 h) tide in the upper intertidal flat at Nanaura, a reduced threshold current velocity on chl a resuspension during neap tide would be understandable.

\section{Dynamics of tidal resuspension}

The dynamics of tidal resuspension of microphytobenthos and sediment in the upper intertidal flat are well described based on the mooring records of chl $a$, SPM, current velocity, and water depth in the context of flood-ebb and spring-neap tidal characteristics.

\section{Flood-ebb characteristics}

Similar patterns of fluctuation in chl $a$ and SPM concentrations during flood-ebb tides and a strong correlation between the concentrations (given as mass $\mathrm{m}^{-2}$ ) indicated their close relationship at shorter time scales (Fig. 7). Concentrations of chl $a$ and SPM during the flood tide and subsequent ebb tide showed an L- or Ushaped curve (see Fig. 3), which represented the resuspension mechanism related to the current velocity during the flood-ebb tidal cycle on the shallow intertidal flat (Baillie \& Welsh 1980). In particular, a sudden peak of SPM and coincident chl a elevation in the early flood-tide period indicated dynamic tidal resuspension of bottom sediment in this area. A large amount of suspended materials containing microphytobenthos would be released from the bottom sediment due to rapid mixing by tidal currents during the early flood period, but suspended materials would then decrease by settling of the fastest falling SPM fraction during the slack water period. Chl a concentrations $>100 \mu \mathrm{g} \mathrm{l}^{-1}$ were rarely found during the ebbing tide, whereas highly elevated chl a (over $\sim 100 \mu \mathrm{g} \mathrm{l}^{-1}$ ) was often observed during the flooding tide (Fig. 3). The relatively low chl a level during late ebb tide would be due to the weaker current velocities during this time. This flood-ebb variability in chl $a$ and SPM concentrations in the water column agreed with earlier results that showed similar temporal fluctuations in the seawater at Hond tidal flat, the Ems estuary, and the Humber estuary, UK (McCandliss et al. 2002, Lucas 2003). When depicted as mass $\mathrm{m}^{-2}$, resuspended $\mathrm{chl} a$ and SPM peaks were usually found shortly after the current velocity maximized, which suggested rapid mixing of bottom sediments by tidal currents and subsequent resuspension by convection currents in combi- nation with tidal currents and wind action (Baillie \& Welsh 1980).

\section{Spring-neap characteristics}

In terms of tidal strength, the spring-neap tidal conditions influenced daily variability in the distributions and fluxes of chl $a$ and SPM in the upper intertidal flat (Figs. 3 \& 5). In general, the concentrations of chl $a$ and SPM in seawater during spring tide were twice as great as those during neap tide. Based on the maximum current velocity recorded, spring-tide current velocity was approximately twice as great as neap current velocity. This indicated that the reduced tidal current might directly influence the lower activity of tidal resuspension during the neap-tide period. This phenomenon was further characterized by great variations in chl $a$ and SPM fluxes during the spring-tide period; net fluxes increased during the spring-tide period. Previous results also showed lower concentrations of resuspended chl a and/or SPM in the water column during neap compared to spring tide, due to weak resuspension activity caused by slow and weak tidal currents, followed by increases in net fluxes of chl a and SPM during spring tidal conditions (Black 1998, Bassoullet et al. 2000). Because the mixing strength and resuspension of bottom sediment into the water column would vary depending on spring-neap tidal conditions, field sampling aimed at monitoring chl a should be carefully designed.

Spring-neap variability in tidal resuspension of chl $a$ and SPM reflected variations similar to the spring-neap tide differences in the distribution of sediment chl $a$ in terms of benthic-pelagic coupling. Here, a decreased concentration of sediment chl a from spring to neap tide could be explained by an average 2-fold decrease in exposure durations from spring to neap tide (Table 4). At the same time, day-night variability in sediment chl $a$ indicated another factor that may influence the distribution of chl $a$ in the upper intertidal flat. Since sediment sampling during neap tide was performed mainly in morning or night periods, the lower sediment chl a during neap tide may be the result of low light conditions. A recent study by Friend et al. (2005) reported significant day-night variation in the sediment chl a from upper intertidal sites of Southampton, UK. They indicated that the light-dark conditions during exposure were found to be the main factor associated with the chl a variability, followed by differences in sediment stability. Thus, the spring-neap variability of chl a distribution in sediment could be attributed to both factors, light conditions as well as exposure durations. Overall, spring-neap characteristics of chl a in seawater and sediment indicated the presence of a greater fraction of resuspended chl a relative to total chl $a$ in the water col- 


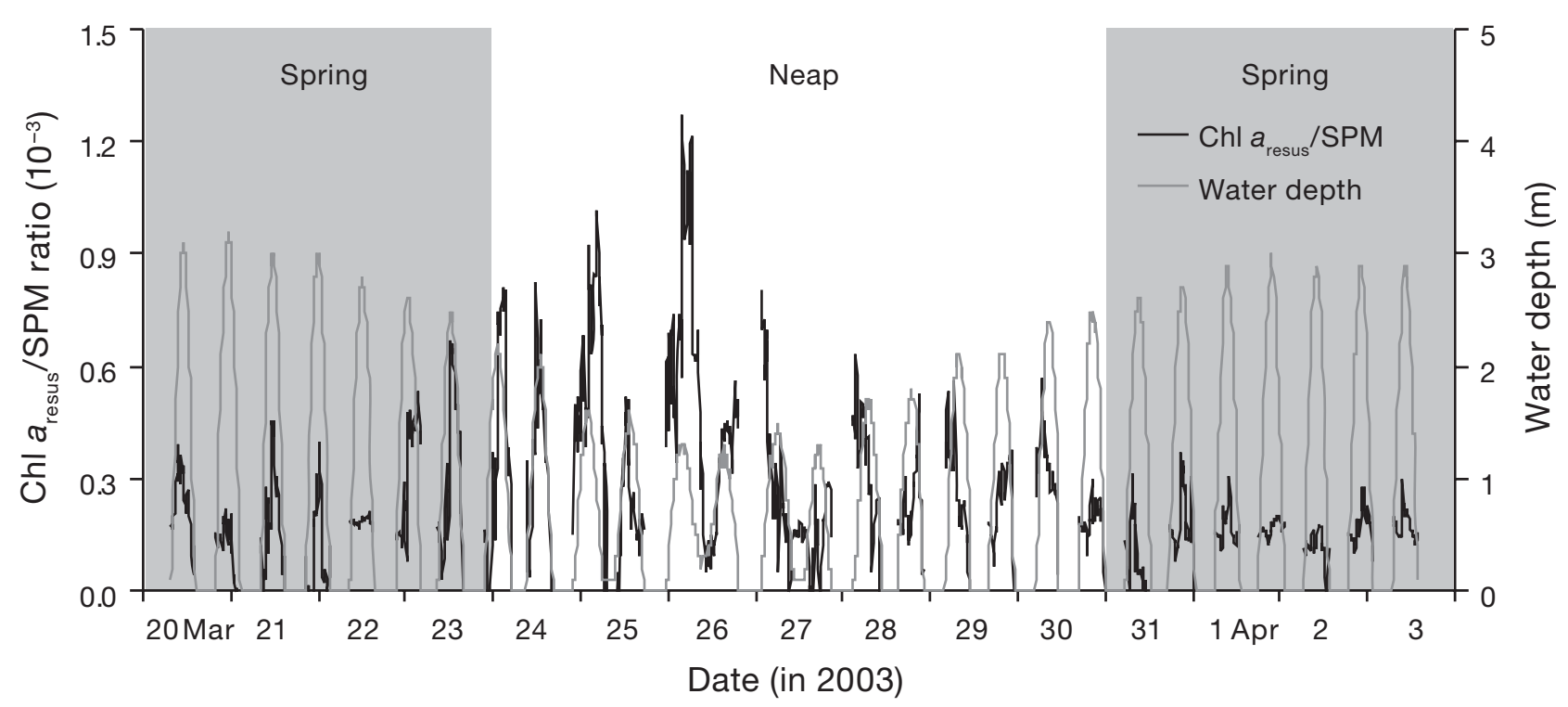

Fig. 8. Ratio of resuspended chl $a_{\text {resus }}$ to suspended particulate matter (SPM) in seawater measured at Stn A from the upper intertidal flat over 28 tidal cycles.

umn during spring than during neap tide. In general, the present data indicated that biomass produced photosynthetically during exposure contributed a portion of chl $a$ to the water column.

\section{Chl a versus SPM}

The relationship between chl a (or resuspended chl a) and SPM represented the flood-ebb and spring-neap tidal characteristics of resuspension dynamics in the upper intertidal flat at Nanaura. There were apparently 2 clearly different patterns in the scatter of data points due to the data depicted from transition periods from accelerating (viz. high tidal energy periods of spring tide) to decelerating tidal conditions (viz. low tidal energy periods of neap tide), supporting the spring-neap differences in strength of SPM resuspension (Fig. 7). In any case, both chl $a$ and resuspended chl a were significantly correlated with the corresponding SPM, but much more strongly correlated during the spring-tide period (Fig. 7). Looking at the relationship between chl $a_{\text {resus }}$ and SPM, great variation was observed in chl $a$, but very little in the corresponding SPM during neap tidal conditions (Fig. 7B). This indicated that chl a may be decoupled from sediment particles and resuspended during flood, although the current velocity remained below the threshold current velocity of ca. $15 \mathrm{~cm} \mathrm{~s}^{-1}$ (see flood in Fig. 6A). This phenomenon could be explained by fluff and/or a surface film of diatoms that developed above the consolidated upper milimeters of sediment (Sutherland et al. 1998). During neap-tide periods without daytime exposure on 25 to 27 March (tidal cycle Nos. 10 to 15), the buoyant biofilms were easily resuspended, even at tidal current velocities of $<10 \mathrm{~cm} \mathrm{~s}^{-1}$, which are usually recorded during early flood tide. This could be further explained by the considerably lower amount of SPM resuspended during neap tide, while resuspension of light chl a remained relatively high. Since the current velocity $\left(<15 \mathrm{~cm} \mathrm{~s}^{-1}\right)$ recorded during the entire period of neap tide was consistently lower than the estimated threshold current velocity of SPM erosion (ca. 15 to $20 \mathrm{~cm} \mathrm{~s}^{-1}$ ), significant SPM resuspension may not be expected during this time (except in periods of high wind speed). However, significant resuspension of light chl a during certain periods of neap tide could be expected; this was supported by moderate to high levels of chl a observed at slower current velocities during the ebb period of neap tide.

Fluctuations in the ratio of chl $a_{\text {resus }} / \mathrm{SPM}$ during flood-ebb and spring-neap tidal cycles represented the resuspension mechanisms of sediment and associated biological particles in the upper intertidal flat (Fig. 8). Generally, over 28 tidal cycles, the chl $a_{\text {re- }}$ sus/SPM ratio gradually increased from early flood and maximized in the high slack water period, probably due to more rapid settlement of heavy suspended particles than resuspended chl a residuals in the water column. This phenomenon was consistently observed for all 28 flood-ebb tidal cycles, indicating segregation of biological particles from suspended mud, followed by settlement of chl $a$ at a slower pace than SPM, from slack water periods until the tide ebbed. On average, the chl $a_{\text {resus }} / \mathrm{SPM}$ during neap tide was more than 
twice that observed during spring tide, reflecting slow settlement of chl a during ebb tide (see also ebb in Fig. 6A). In particular, the maximum peak ratio of chl $a_{\text {resus }} /$ SPM was found to be as high as 0.00127 (viz. $1270 \mathrm{\mu g} \mathrm{g}^{-1}$ ) on 26 March (tidal cycle No. 12), during the neap high slack water period, at a current velocity of $3.5 \mathrm{~cm} \mathrm{~s}^{-1}$. Thus, the greater $\mathrm{chl} a_{\text {resus }} / \mathrm{SPM}$ during the neap tidal period (e.g. tidal cycles Nos. 8 to 14) was likely due to the relatively low concentrations and low variability of heavy SPM associated with the reduced tidal current during this time.

\section{Ecological implications}

The presence and contribution of resuspended microphytobenthic chl $a$ in the water column, along with sediment resuspension and its ecological implications in terms of benthic-pelagic coupling have beenwell documented elsewhere (de Jonge \& van Beusekom 1992, 1995, de Jonge 1995, Lucas et al. 2000, 2001). Previous findings by de Jonge (1995) indicated that a substantial amount (30\% for the lower reaches and 92\% for the Dollard) of chl $a$ in the water column was derived from suspended microphytobenthos. In the present study, the overall contribution of resuspended chl a to total chl $a$ in the upper intertidal flat ranged from 9 to $61 \%$, with an average of $42 \%$. The differences in chl a resuspension activity during the observation period of 28 tidal cycles were primarily associated with the tidal current speed and, to a lesser extent, a wind effect. As current velocity decreased from spring to neap tidal conditions, the active tidal resuspension of microphytobenthos during early flood was subsequently reduced and became less significant. Relatively, the wind effect on tidal resuspension of chl $a$ and SPM was less significant, but rather episodic and unpredictable. However, the net transport of chl $a$ and SPM at the end of 21 March, which showed the same magnitude as all of the following periods until the end of 3 April, indicated that the episodic wind event may have had a substantial effect on horizontal flux and transport in the upper intertidal flat. Thus, in the upper intertidal flat at Nanaura, both the tidal current and wind waves could influence tidal resuspension itself, as well as the transport of materials back and forth between the tidal flats.

The mechanism of tidal resuspension was clearly characterized by flood-ebb and spring-neap distributions of resuspended chl $a$ and SPM in the water column of the upper intertidal flat, where a great contribution of resuspended chl a in the water column was observed under early flood and spring tidal conditions. Also, analysis of the relationship between chl $a$ and SPM (including the chl $a_{\text {resus }} /$ SPM ratio) indicated their coupling or decoupling behavior in response to tidal condition, viz. strength of current velocity. Calculation of chl $a$ and SPM fluxes further indicated net offshore transportation of sediment together with biological particles. From the cross-section data analyzed, the ratio of chl a/SPM increased from the upper intertidal to the subtidal (up to $1.5 \mathrm{~km}$ off the coastline), but rapidly decreased approaching offshore locations. Thus, the offshore transportation of chl a and SPM may influence the distributions and/or fluxes of resuspended chl a and SPM within this boundary. Consequently, the resuspended portion of chl a and/or SPM would not be expected to be great past $1.5 \mathrm{~km}$. The relatively large proportion of resuspended chl $a$, compared to sediment chl a (up to $71 \%$ in the upper intertidal flat) implied that the sediment itself plays an important role as a chlorophyll reservoir and, at the same time, supplies a certain amount of the microphytobenthos produced to the water column during submergence.

\section{CONCLUSIONS}

The present study suggested that: (1) the temporal distributions of chl $a$ and SPM in the water column from the upper intertidal flat were similar and clearly associated with flood-ebb and spring-neap tidal characteristics, (2) the regular resuspension of chl $a$ and SPM at early flood tide was primarily associated with increased tidal energy (viz. current velocity), and the threshold current velocity of their resuspension was estimated to be ca. $15 \mathrm{~cm} \mathrm{~s}^{-1}$, (3) wind-induced resuspension could explain irregular, high fluctuation of chl $a$ and SPM during submergence, the effect of which was approximately twice that of tide-induced resuspension during periods of high wind speed ( $\geq 3 \mathrm{~m} \mathrm{~s}^{-1}$ ), (4) the fluxes of chl $a$ and SPM broadly reflected increasing or decreasing tidal energy throughout the full spring-neap tidal periods, and timeintegrated residual fluxes were predominantly offshore, and finally (5) benthic chl $a$ in surficial sediment showed temporal variation similar to that observed for chl $a$ in the water column during the semi-lunar tidal cycle, and $>30 \%$ of the resuspended chl $a$ in the water column was attributable to benthic chl $a$ in the upper intertidal flat at Nanaura, Ariake Sea, Japan.

Acknowledgements. The present study was conducted during a guest professorship of C.-H.K. at the Institute of Lowland Technology (ILT), Saga University, Japan, from April 2002 to March 2003. We thank Prof. Hayashi, who arranged the guest professor program including financial support, and Miss Yahiro in the ILT office for her kind help in administrative work during this time. We also thank Dr. Villeneuve at the US EPA, Duluth, for his kind review and corrections of the manuscript and deeply appreciate the valuable and kind comments of the reviewers and editor during review. This study was conducted as part of a research program entitled 'Technological 
development for bottom sediment improvement and benthos restoration in the Ariake Sea', financially supported by the Research and Development Program for New Bio-industry Initiatives (2001-03), Japan. Additional support was provided by the Korean Sea Grant Project (2001-03), Ministry of Maritime Affairs \& Fisheries, Korea, under the subject title 'An estimation of biomass and production of benthic microalgae in coastal sediment, Korea'.

\section{LITERATURE CITED}

Baillie PW, Welsh BL (1980) The effect of tidal resuspension on the distribution of intertidal epipelic algae in an estuary. Estuar Coast Mar Sci 10:165-180

Bassoullet PH, Hir PL, Gouleau D, Robert S (2000) Sediment transport over an intertidal mudflat: field investigations and estimation of fluxes within the 'Baie de MarennesOleron' (France). Cont Shelf Res 20:1635-1653

Black KS (1998) Suspended sediment dynamics and bed erosion in the high shore mudflat region of the Humber Estuary, UK. Mar Pollut Bull 37:122-133

Blanchard GF, Guarini JM, Orvain F, Sauriau PG (2001) Dynamic behaviour of benthic microalgal biomass in intertidal mudflats. J Exp Mar Biol Ecol 264:85-100

de Jonge VN (1995) Wind-driven tidal and annual gross transport of mud and microphytobenthos in the Ems Estuary, and its importance for the ecosystem. In: Dyer KR, Orth RJ (eds) Changes in fluxes in estuaries. Olsen \& Olsen, Fredensborg, p 29-40

de Jonge VN, Colijn F (1994) Dynamics of microphytobenthos biomass in the Ems estuary. Mar Ecol Prog Ser 104:185-196

de Jonge VN, van Beusekom JEE (1992) Contribution of resuspended microphytobenthos to total phytoplankton in the Ems estuary and its possible role for grazers. Neth J Sea Res 30:91-105

de Jonge VN, van Beusekom JEE (1995) Wind- and tideinduced resuspension of sediment and microphytobenthos from tidal flats in the Ems estuary. Limnol Oceanogr 40:766-778

de Jonge VN, van den Bergs J (1987) Experiments on the

Editorial responsibility: Victor de Jonge (Contributing Editor), Haren, The Netherlands resuspension of estuarine sediments containing benthic diatoms. Estuar Coast Shelf Sci 24:725-740

Demers S, Therriault JC, Bourget E, Bah A (1987) Resuspension in the shallow sublittoral zone of a macrotidal estuarine environment: wind influence. Limnol Oceanogr 32:327-339

Friend PL, Lucas CH, Rossington SK (2005) Day-night variation of cohesive sediment stability. Estuar Coast Shelf Sci 64:407-418

Jago CF, Jones SE, Latter RJ, McCandliss RR, Hearn MR, Howarth MJ (2002) Resuspension of benthic fluff by tidal currents in deep stratified waters, northern North Sea. J Sea Res 48:259-269

Lorenzen CJ (1967) Determination of chlorophyll and pheopigments: spectrophotometric equations. Limnol Oceanogr 12:343-346

Lucas CH (2003) Observation of resuspended diatoms in the turbid tidal edge. J Sea Res 50:301-308

Lucas CH, Widdows J, Brinsley MD, Salkeld PN, Herman PMJ (2000) Benthic-pelagic exchange of microalgae at a tidal flat. 1. Pigment analysis. Mar Ecol Prog Ser 196:59-73

Lucas CH, Banham C, Holligan PM (2001) Benthic-pelagic exchange of microalgae at a tidal flat. 2. Taxonomic analysis. Mar Ecol Prog Ser 212:39-52

Lucas CH, Widdows J, Wall L (2003) Relating spatial and temporal variability in sediment chl $a$ and carbohydrate distribution with erodability of a tidal flat. Estuaries 26: 885-893

McCandliss RR, Jones SE, Hearn M, Latter R, Jago CF (2002) Dynamics of suspended particles in coastal waters (southern North Sea) during a spring bloom. J Sea Res 47 : 285-302

Sutherland TF, Amos CL, Grant J (1998) The effects of buoyant biofilm on the erodibility of sublittoral sediments of a temperate microtidal estuary. Limnol Oceanogr 43:225-235

Widdows J, Brown S, Brinsley MD, Salkeld PN, Elliott M (2000) Temporal changes in intertidal sediment erodability: influence of biological and climatic factors. Cont Shelf Res 20:1275-1289

Wolk F, Seuront L, Yamazaki H (2001) Spatial resolution of a new micro-optical probe for chlorophyll and turbidity. J Tokyo Univ Fish 87:13-21

Submitted: November 11, 2004; Accepted: October 10, 2005 Proofs received from author(s): March 16, 2006 